\title{
Stratigraphy and Paleontology of
}

the Revised Type Section for the Tahkandit Limestone (Permian) in East-Central Alaska

GEOLOGIGAL SURVEY PROFESAIONAL PAPER 703

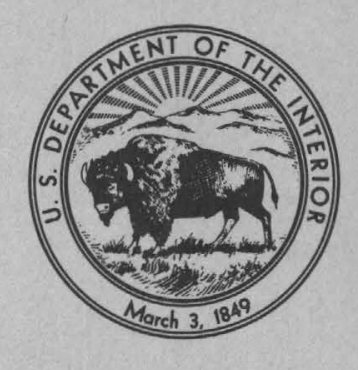



Stratigraphy and Paleontology of the Revised Type Section for the Tahkandit Limestone (Permian) in East-Central Alaska

By EARL E. BRABB and RICHARD E. GRANT

GEOLOGICAL SURVEY PROFESSIONAL PAPER 703

Revisions in the definition, description, and

paleontology of an Arctic Permian formation

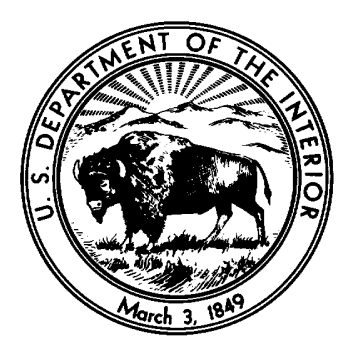

UNITED STATES GOVERNMENT PRINTING OFFICE, WASHINGTON : 1971 


\section{UNITED STATES DEPARTMENT OF THE INTERIOR \\ ROGERS G. B. MORTON, Secretary}

\section{GEOLOGICAL SURVEY}

W. A. Radlinski, Acting Director

Library of Congress catalog-card No. 70-611771

For sale by the Superintendent of Documents, U.S. Government Printing Office Washington, D.C. 20402 - Price 50 cents (paper cover)

Stock Number 2401-1134 


\section{CONTENTS}

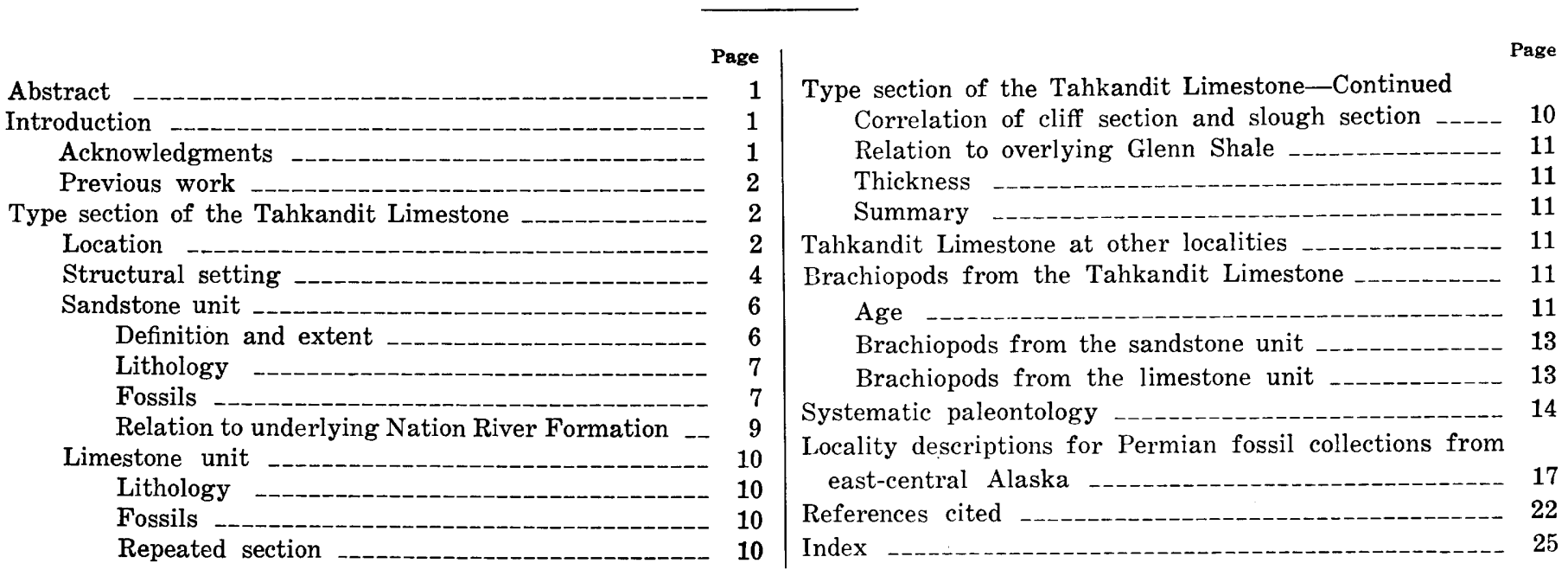

\section{ILLUSTRATIONS}

[Plates follow index]

Plate 1. Fossils from the Tahkandit Limestone.

2. Fossils from the Tahkandit Limestone.

Figure 1. Map showing location of type section of Tahkandit Limestone

Page

2-4. Photographs showing-

2. Location of original and revised type section

3. Section along Yukon River slough

4. Enlarged view of cliff section

5. Stratigraphic sections of the Tahkandit Limestone in its type section

6. Sketch of geology at type section

7. Photomicrograph showing sandstone texture

8. Photomicrograph showing prismatic pelecypod fragments

9. Photograph showing contact between the Tahkandit Limestone and the Nation River Formation

10. Photomicrograph showing fossil fragments cemented by calcite

11. Photomicrograph showing bioclastic limestone characteristic of the limestone unit of the Tahkandit Limestone - 10

\section{TABLES}

TABLE 1. Brachiopods from the type section of the Tahkandit Limestone

Page

2. Brachiopods from the Tahkandit Limestone outside the type section

3. Locality descriptions for Permian fossil collections from east-central Alaska 



\title{
STRATIGRAPHY AND PALEONTOLOGY OF THE REVISED TYPE SECTION FOR THE TAHKANDIT LIMESTONE (PERMIAN) IN EAST-CENTRAL ALASKA
}

\author{
By Earl E. Brabb and Richard E. Grant
}

\begin{abstract}
The type section for the Tahkandit Limestone is revised to include a massive cliff-forming limestone that apparently is displaced by a fault from the type section specified by Mertie (1930) as being along a slough of the Yukon River. Some of the limestone and sandstone in the slough section, on the other hand, seems to be repeated by faulting and is herein excluded from the type section. Also excluded are rocks that are more properly assigned to the underlying Nation River Formation of Late Devonian age. The Tahkandit type section is redefined to include a lower sandstone unit about 75 feet thick and an upper limestone unit about 270 feet thick. The combined thickness of about 345 feet is considerably less than the 527 or 2,065 feet reported previously.

Abundant brachiopods from known stratigraphic positions within the Tahkandit are illustrated and discussed systematically for the first time. The faunas show affinities to Permian faunas in the Canadian Arctic Archipelago and central east Greenland and are probably correlative with the upper Leonard and lower Guadalupe Provincial Series of the Southwestern United States.
\end{abstract}

\section{INTRODUCTION}

Alaskan fossils of Permian age have been mentioned in many geologic reports since the late 1800 's, but hardly any have been described or illustrated. The general character of one of these faunas, from the Tahkandit Limestone near the mouth of the Nation River in east-central Alaska (fig. 1), was described in a report by Mertie (1930, p. 125-126), but many of the fossil names that he listed are obsolete, and the stratigraphic position and evolutionary sequence of the fossils are unknown. Our report is, therefore, the first to describe and illustrate Tahkandit brachiopods from known positions within the type section, and it is the first illustrated report of Permian brachiopods from Alaska.

Investigation of the Tahkandit Limestone is part of a project begun in 1960 to map the geology of eastern Alaska at a scale of 1:250,000. Preliminary geologic maps showing the type area of the Tahkandit Limestone and surrounding region were first released in open files of the U.S. Geological Survey (Brabb, 1962; Brabb and Churkin, 1964, 1965), and one was later revised and published (Brabb and Churkin, 1969). A simplified geologic map which shows the type area at an approximate scale of $1: 55,000$ is in a report by Brabb and Churkin (1967, fig. 4).

\section{ACKNOWLEDGMENTS}

H. J. Roepke and R. N. Passero ably assisted Brabb in 1960 in collecting fossils from the type Tahkandit Limestone, measuring sections, and describing the rocks. J. C. Melik and R. L. Taylor in 1961 and D. L. Giles in 1962 assisted in collecting additional Tahkandit fossils. Michael Churkin, Jr., of the U.S. Geological Survey joined the project in 1962, mapped several areas underlain by the Tahkandit Limestone, and collected several Tahkandit fossils. Churkin and E. W. Bamber of the Geological Survey of Canada collected from the type section of the Tahkandit in 1963. Brabb, Grant, and Bamber, along with A. K. Armstrong of the U.S. Geological Survey, collected fossils from the type section again in 1967. We thank these colleagues for their extensive help and support. Armstrong also kindly identified the fossils shown on the photomicrographs. We also extend thanks to S. J. Nelson of the University of Alberta and J. T. Dutro, Jr., of the U.S. Geological Survey for their assistance. Grant is responsible for the identification and age of brachiopods and for the sections entitled "Brachiopods from the Tahkandit Limestone" and "Systematic Paleontology." 


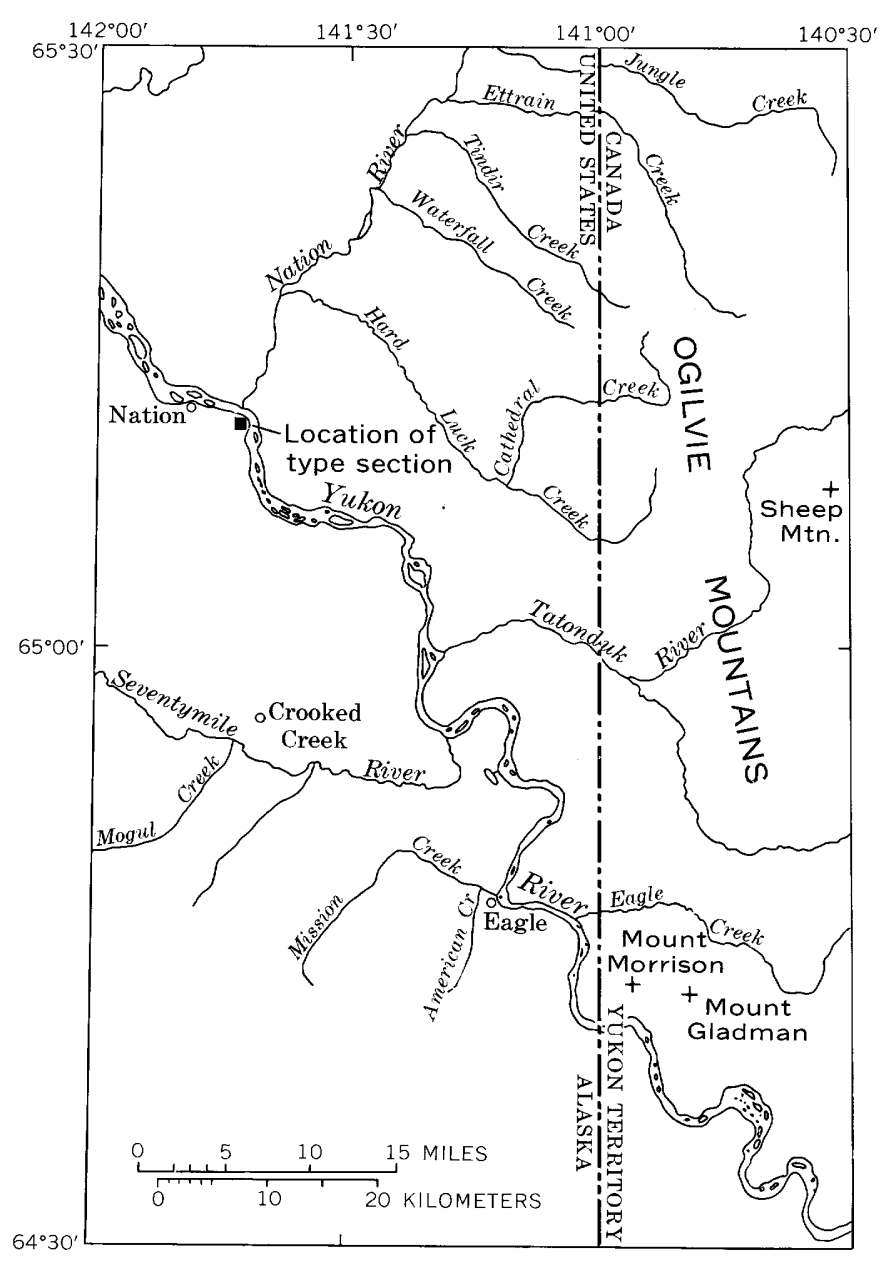

FIgURE 1.-Location of type section of Tahkandit Limestone.

\section{PREVIOUS WORK}

Tahkandit, an Indian name for the Nation River, was first used by Spurr $(1898$, p. 169-174) for a "series" of limestone, shale, and conglomerate of Devonian to "late Carboniferous" (which then included the Permian) age exposed along the upper reaches of the Yukon River and its tributaries. Spurr's Tahkandit Series included a white limestone and basal sandstone and conglomerate referred to as the Tahkandit Limestone in this report, the underlying Nation River Formation of Late Devonian age, and other rocks as old as Precambrian(?) and as young as Cretaceous. Mertie (1930, p. 121) restricted Spurr's Tahkandit Series to the white limestone and basal sandstone and conglomerate of Permian age, and he named these rocks the Tahkandit Limestone. His report has served until now as the standard reference for the Tahkandit at its type locality.

Nelson (1961a) extended the name Tahkandit Formation to the Ogilvie Mountains, Yukon Territory, Canada (fig. 1). The formation there is as much as
1,000 feet thick, more than three times as thick as in Alaska. It contains abundant spicular chert and siltstone (Bamber and Barss, 1969) not found in the formation at its type section, and it overlies formations not recognized in Alaska. There is some doubt, therefore, about the appropriateness of the name Tahkandit for this formation in the Yukon Territory. In a report describing corals from the formation, Nelson (1962a) emphasized that assignment of these rocks to the Tahkandit was provisional and possibly incorrect. Nelson found fusulinids of Permian (Leonard) age in the Yukon Tahkandit, and he illustrated some of the characteristic brachiopods. Additional brachiopods from the Tahkandit of the Yukon Territory were described and illustrated by Nelson (1962b) and Nelson and Johnson (1968). Fusulinids also from the Yukon Tahkandit were described and illustrated by Ross (1967); Skinner and Wilde (1966) reported on fusulinids from a stream cobble that could have come from the same formation. Barss (1967) prepared a preliminary report on sporomorphs from the Yukon Tahkandit, and Bamber and Barss (1969) described the palynology and stratigraphy of this formation in greater detail. The present report discusses recent work on the Tahkandit Limestone in Alaska in relation to specific stratigraphic and structural problems.

\section{TYPE SECTION OF THE TAHKANDIT LIMESTONE LOCATION}

There is, unfortunately, some ambiguity concerning the location of the type section that Mertie (1930) described. He stated (p. 121)

The type locality is along the Yukon just above the mouth of the Nation River *** where a belt of such rocks crosses the Yukon, trending northeast (see pl. 10A).

The illustration referred to shows prominent outcrops of the Tahkandit Limestone on the northeast valley slope of the Yukon River, and Laudon, Hartwig, Morgridge, and Omernik (1966, p. 1874) interpreted these outcrops to be the type section. However, Mertie also stated (p. 122)

The best section is seen along the southwest bank of the Yukon, where both the overlying and underlying rocks are exposed (see fig. 6).

Formal stratigraphic language has changed over the years, and Mertie's "type locality" and "best section" would now be termed "type area" and "type section," respectively.

The type section designated by Mertie is exposed inconspicuously along a narrow slough of the Yukon River (figs. 2 and 3) in the northwest corner of sec. 17, 


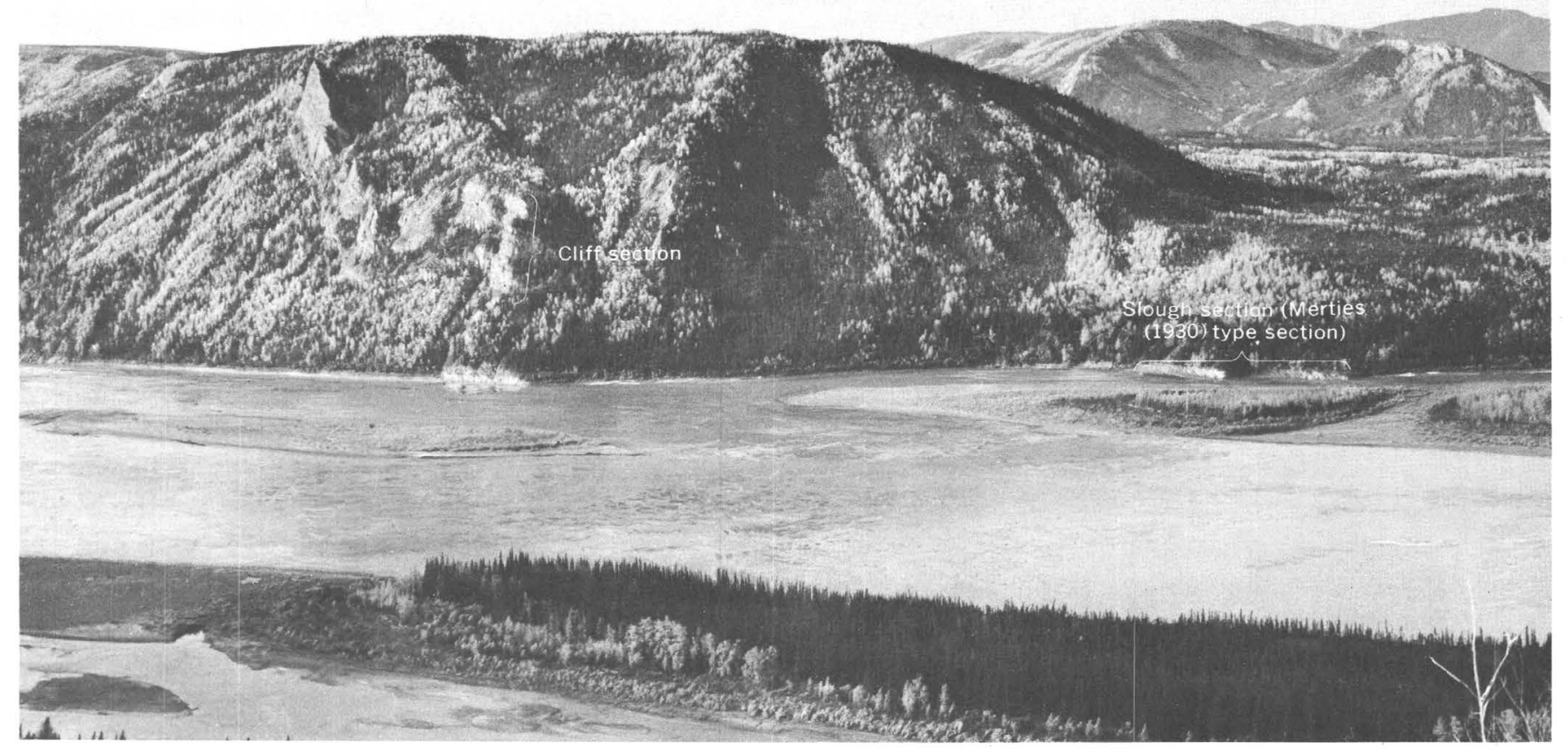

FIGURE 2.-View of slope on southwest side of Yukon River near mouth of Nation River showing location of the slough and cliff sections, the composite type section of the Tahkandit Limestone. See figure 3 for an enlarged view of the slough section and figure 4 for an enlarged view of the cliff section. View southwest.

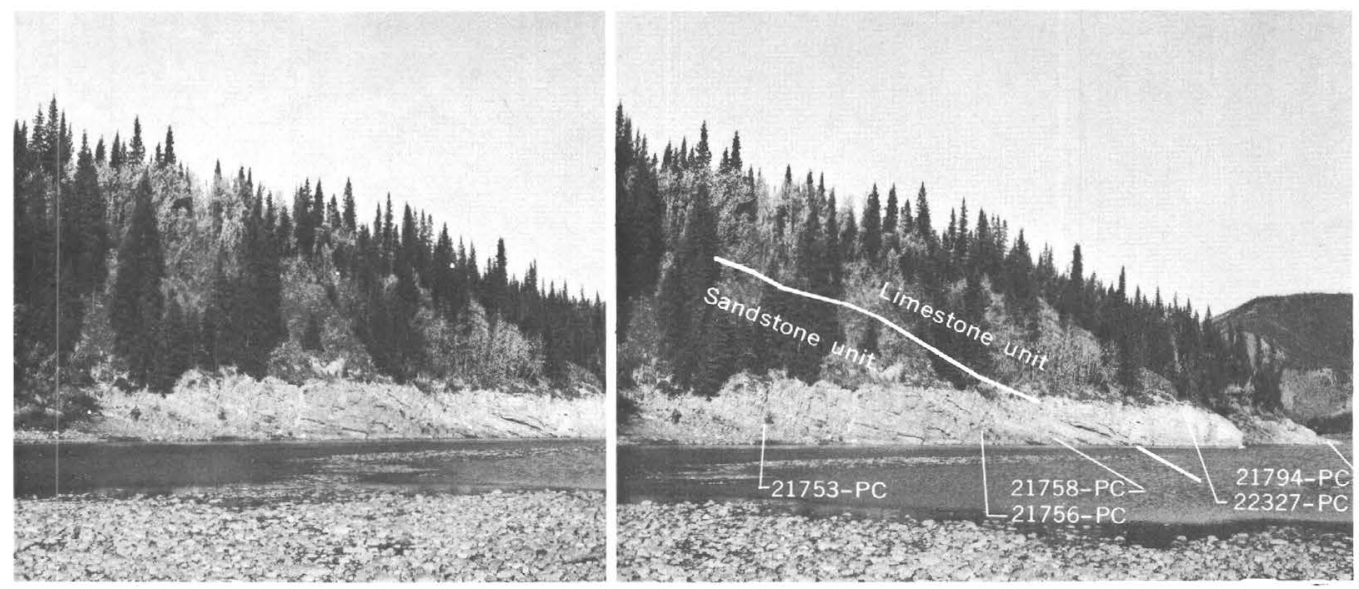

Figure 3.- Stereogram showing Yukon River slough section of Tahkandit Limestone. Man at left is standing on contact between Tahkandit (above) and Nation River (below) Formations. See figure 9 for a view of this contact. Limestone beds forming the rocky points at localities 22327-PC and 21794-PC are separated by a covered interval which is thought to conceal a fault. Numbers refer to fossil collections and localities described in text. View northwest. 
T. 4 N., R. 30 E., lat $65^{\circ} 10.8^{\prime}$ N., long $141^{\circ} 41.9^{\prime}$ W. (Charley River A-2 quad.). Many of the rocks and particularly the overlying Triassic sequence are exposed only when the Yukon River is low. In addition, the slough is being filled with silt and gravel, so that some of the section observed by Mertie and earlier geologists from 1897 to 1930 can no longer be seen, even when river level is very low.

The section along the slough is considered to be incomplete and is herein revised so that it includes, in addition, the prominent limestone cliff several hundred feet upstream (south) (see fig. 2). The rocks that have been added to the type section are in the vicinity of the numbered localities shown in figure 4. In this report the term "slough section" will be used to refer to Mertie's type section, "cliff section" will be used for the upper part of the revised type section, and "type section" will be used for the combined slough and cliff sections.

One additional refinement of this terminology is needed. We believe that the slough section includes parts of the Tahkandit Limestone repeated by faulting. These repeated rocks, in the vicinity of locality 21794-PC (fig. 3), are herein excluded from the revised type section. Figure 5 shows the inferred correlation of this repeated section with the composite type section. To summarize, the composite type section for the Tahkandit Limestone, as defined herein, includes the rocks from the vicinity of localities 21752-PC to 22328-PC in the slough section and from localities 21746-PC to 21751-PC in the cliff section.

\section{STRUCTURAL SETTING}

The slough section shown diagrammatically by Mertie (1930, fig. 6) is, unfortunately, a mirror image of the locality as viewed from the Yukon River. We have, therefore, sketched the geology at the type section as an observer sees it; the sketch (fig. 6) shows the slough and cliff sections and provides an interpretation of the local structure. (See also figs. 2-4.)

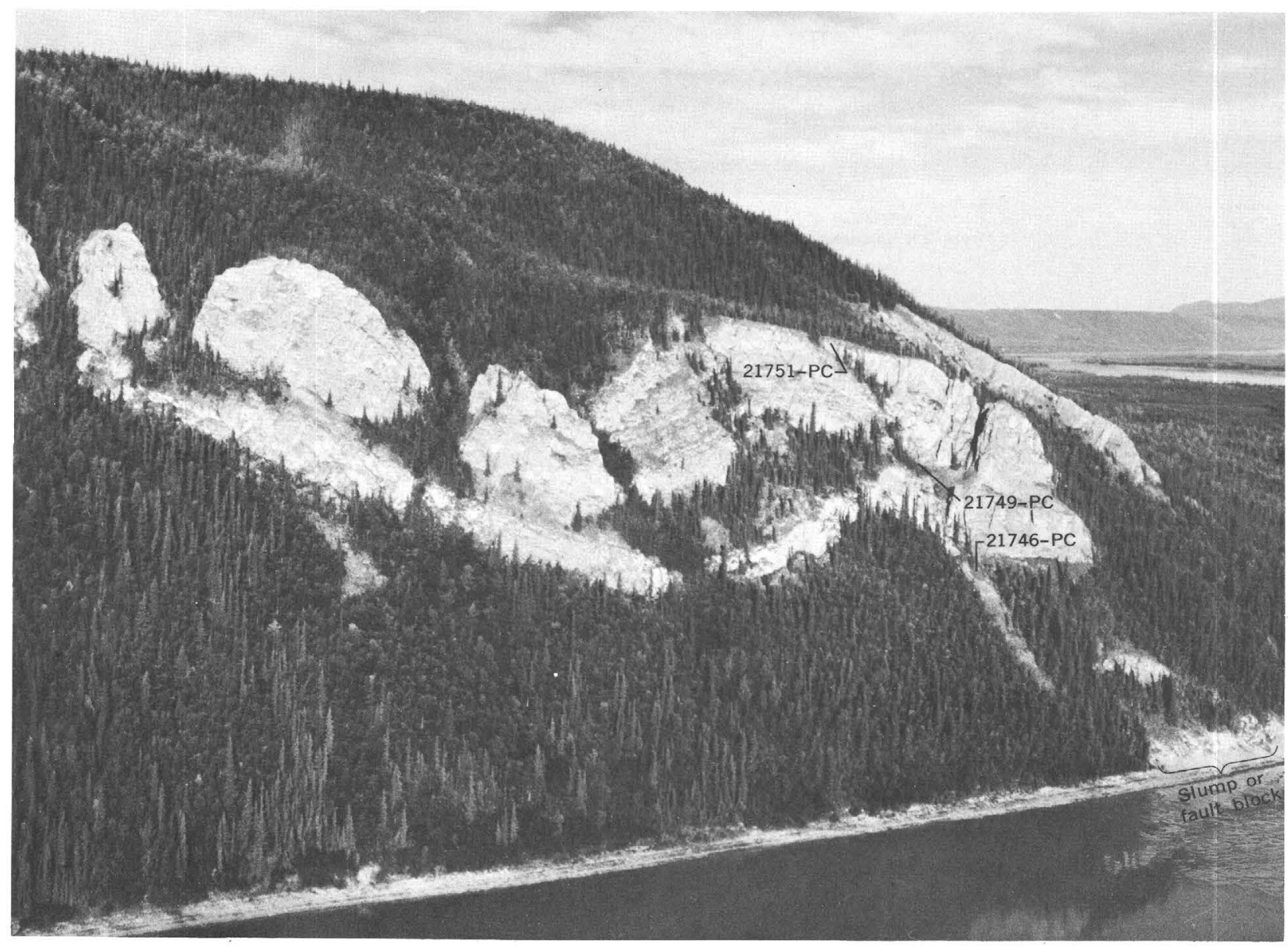

FiguRE 4.-Enlarged view of cliff section of Tahkandit Limestone shown in figure 2. Numbers refer to fossil localities described in text. Note the slump or fault block of limestone at lower right. View northwest. 
EXPLANATION

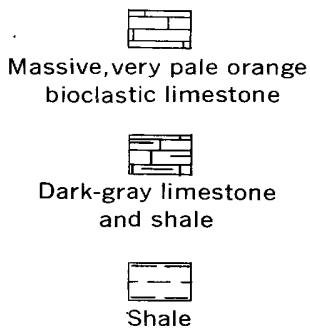

3

Inferred repeated section of Tahkandit Limestone showing relation of overlying Glenn Shale along Yukon River slough
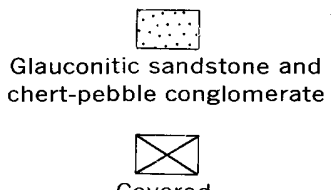

21750-PC •

U.S Geological Survey fossil collection number

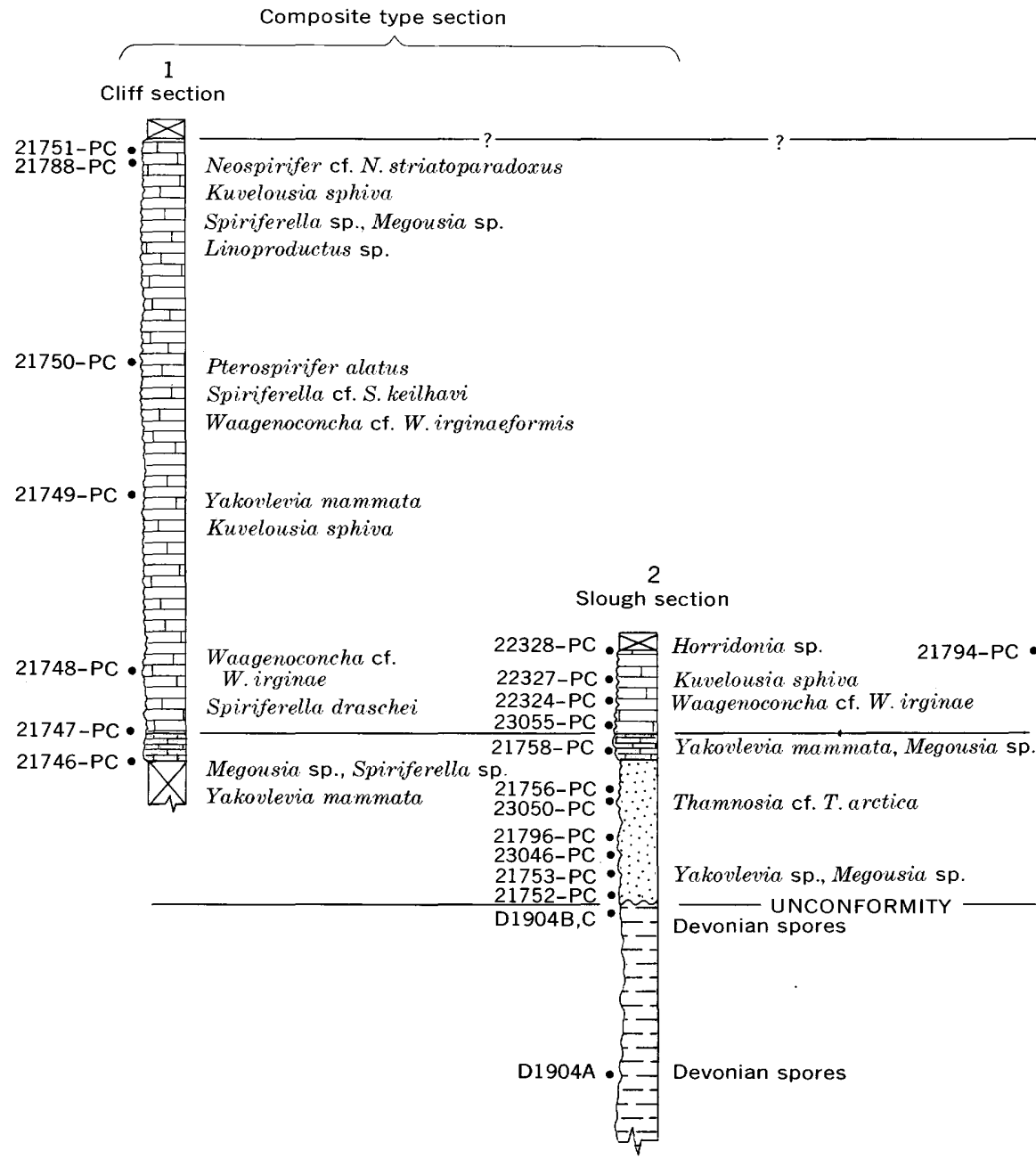

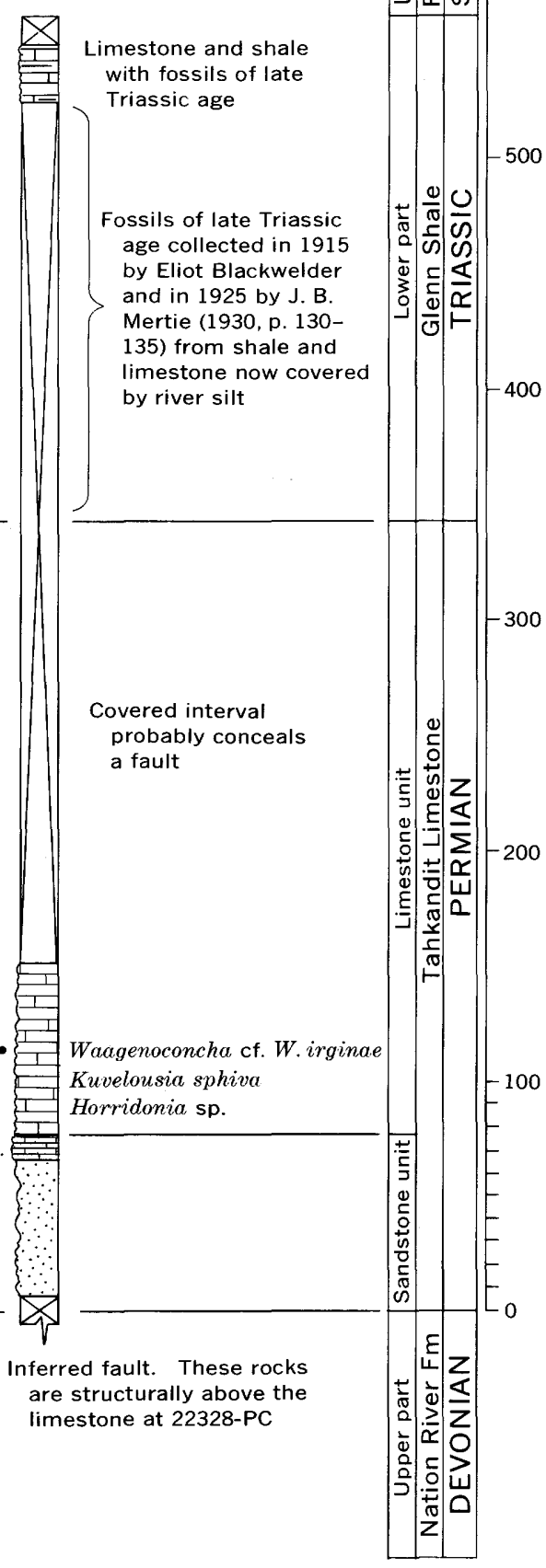

FIgURE 5.-Stratigraphic columns of the Tahkandit Limestone in its type section. See table 1 for a more complete list of fossils and the text for a description of each Permian and Carboniferous (PC) locality. D-numbers are spore samples described by Scott and Doher (1967) and Brabb and Churkin (1967). See figures 2-4 for the locations of the columns and figure 6 for the structural setting. 


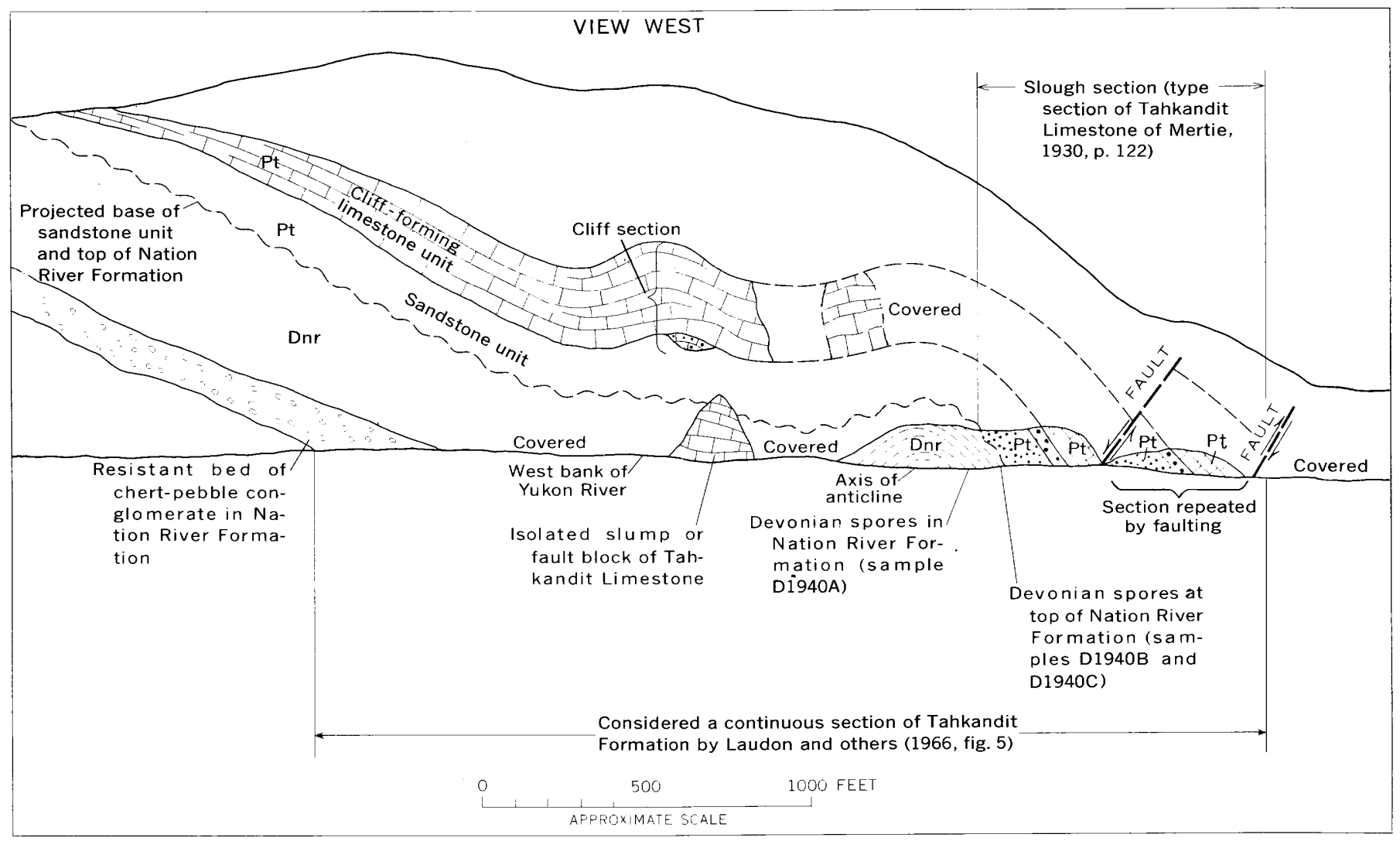

FIGURE 6.-Sketch of relations between the Tahkandit Limestone $\left(P_{t}\right)$ and the Nation River Formation (Dnr) on the southwest bank of the Yukon River opposite the mouth of the Nation River. Numbers refer to spore samples described by Scott and Doher (1967) and Brabb and Churkin (1967).

We and Mertie assign shale beneath the Tahkandit in the slough section to the Nation River Formation, and we believe that this shale forms an anticline, shown in figure 6 . Spores from the shale are Devonian and are comparable to spore assemblages from the Nation River Formation at other localities (Scott and Doher, 1967; Brabb and Churkin, 1967). On the other hand, others seem to have overlooked the anticline and placed the shale in the middle of their so-called Tahkandit Formation (Laudon and others, 1966, fig. 5, 1,183-1,414 ft). What we interpret as a slump or fault block (figs. 4 and 6) forms the interval from 1,005 to about 1,180 feet in Laudon's Tahkandit section, and it is apparently represented as a synclinal segment in Mertie's diagram (1930, fig. 6).

Still unresolved is the report by Laudon, Hartwig, Morgridge, and Omernik (1966, p. 1876-1877; fig. 5) of productid brachiopods in a resistant bed of chertpebble conglomerate; although Laudon and his colleagues described the conglomerate as forming the Tahkandit Formation (see fig. 6), we believe it is well within the Nation River Formation. No brachiopods have ever been found in rocks definitely belonging to the Nation River Formation, and their occurrence in this conglomerate would probably require drastic revision of the structural interpretation. In 1967 we searched for these brachiopods with A. K. Armstrong and E. W. Bamber, but the only fossils we found were the abundant plant fragments that also characterize the Nation River Formation at other localities. The report of brachiopods in the chert-pebble conglomerate seems, therefore, to be in error.

Evidence for the faults shown in the slough section in figure 6 will be discussed in another part of this report.

\section{SANDSTONE UNIT \\ Definition and Extent}

The oldest beds of the Tahkandit Limestone in the type section as herein revised consist of about $\mathbf{7 5}$ feet of glauconitic sandstone, chert-pebble conglomerate, and sandy and glauconitic limestone. For con- 
venience, these rocks are referred to in this report as the sandstone unit. The sandstone unit has not yet been recognized outside the type section, but it could be present elsewhere and covered by more resistant talus from overlying massive limestone beds. If subsequent work shows that the sandstone unit also occurs in other areas beneath the massive limestone that characterizes the Tahkandit, then the sandstone unit should be proposed formally as a member.

\section{Lithology}

The sandstone that forms most of the sandstone unit is an arenite consisting primarily of fairly angular chert and quartz grains. Calcite is also common, and in some of the sandstone it is in the form of fossil fragments. Rounded glauconite grains are so abundant in some of the sandstone that the rock is bright green.

Seven thin sections were made of the sandstone, and in a few of these it appears as though some of the chert, quartz, calcite, and glauconite has been dissolved and redeposited. Angular authigenic quartz commonly coats well-rounded quartz grains. The rock is well sorted, as shown in figure 7, but all the pore spaces have been filled with these secondary minerals. No clay was found in any of the sandstone beds.

The sandstone is generally in beds from a fraction of an inch to a few inches thick. Some of the beds are a few feet thick. The weathered appearance of the beds, shown in figure 3 , is blocky and less massive than that of the overlying limestone.

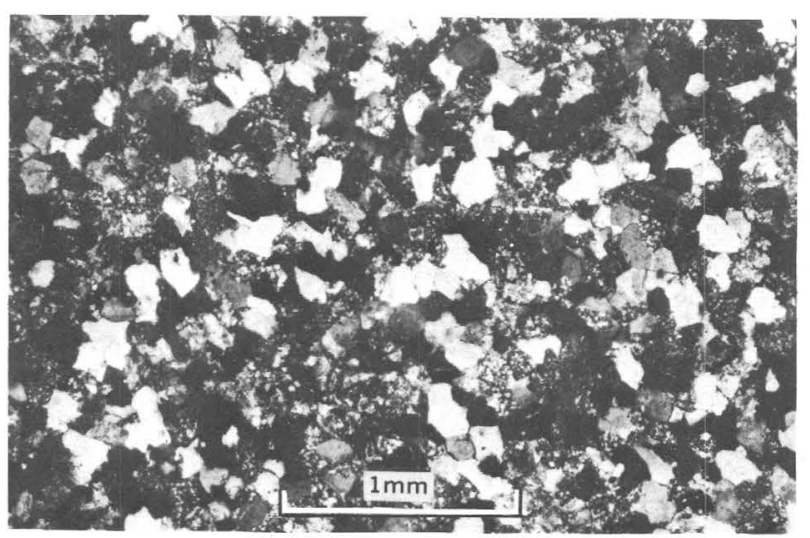

Figure 7.-Photomicrograph of texture of a finegrained sandstone representative of the sandstone unit (loc. 21752-PC; cross-polarized light). Eventextured white, gray, and black grains are chiefly quartz; the black and white speckled grains consist of chert and calcite.
Chert-pebble conglomerate and grit are interbedded with the sandstone. The chert clasts are gray, green, white, black, and red, and they are generally well rounded. Some of the beds have scourand-fill structures.

The sandstone and conglomerate are about 60 feet thick, and they grade vertically upward, near locality 21758-PC (see fig. 3), into about 15 feet of thickly bedded sandy and glauconitic limestone. The calcite in the limestone consists largely of algal, bryozoan, pelmatozoan, and brachiopod fragments 1-2 $\mathrm{mm}$ in maximum dimension, and partly of secondary calcite that has filled spaces between the fossil fragments. This limestone, considered the uppermost bed in the sandstone unit, grades into massive, relatively sand- and glauconite-free limestone that forms the beautiful pinnacles and cliffs at many localities in the vicinity of the Nation River. This massive limestone, referred to for convenience as the limestone unit, will be described in a later section of the report.

Fossils

Brachiopods are the most abundant fossils in the sandstone unit. They are listed in stratigraphic order in table 1 and described in greater detail in the systematic paleontology section. They indicate that the sandstone unit is of Early Permian age and probably equivalent to the upper part of the Leonard Series of the Southwestern United States. Corals and foraminifers are fairly common, but they have not yet been examined. A gastropod at locality 21757-PC was examined by E. L. Yochelson who determined that it is a new genus (written commun., 1965). Two samples of glauconitic sandstone from the upper part of the sandstone unit were submitted for spore and pollen analysis to Richard A. Scott who reported (written commun., 1963),

Collections 60ABa672EA and 60ABa672GA contain trilete spores and bisaccate pollen grains, including striate bisaccates typical for Permian time. Some hystrichosphaerids are also present suggesting a brackish or marine environment.

Several collections of pelecypods from the sandstone unit were examined by John Pojeta, Jr. (written commun., 1965), but few of the fossils were preserved well enough for even generic identification. Figure 8 shows a thin section of one of these pelecypods that displays prismatic structure. Similar calcite prisms are the principal constituent of limestones of Permian and Cretaceous age in other regions of Alaska (Brosgé and others, 1969), but the prisms are scarce in thin sections of the Tahkandit Limestone. 
TABLE 1.-Brachiopods from the type section of the Tahkandit Limestone

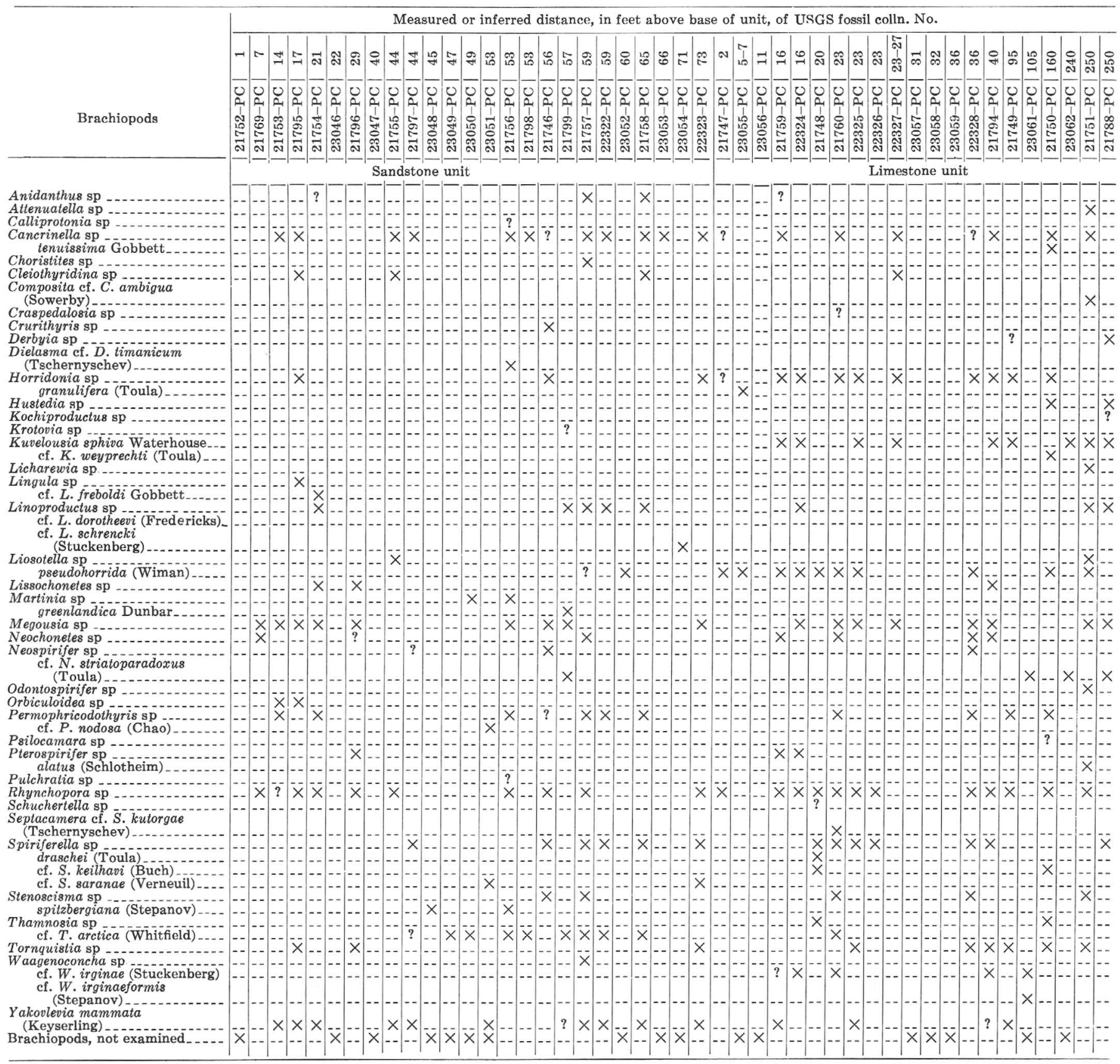




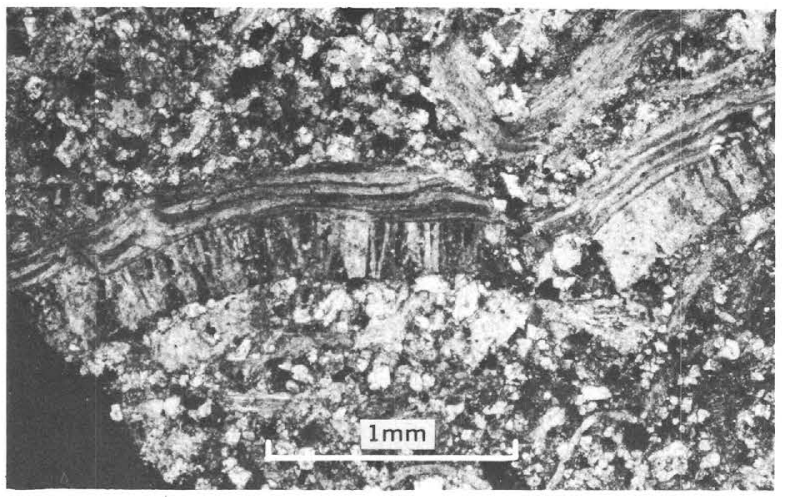

FIGURE 8.-Photomicrograph of calcarenite about 65 feet above the base of the sandstone unit (loc. 21758-PC; cross-polarized light). The pelecypod shell that displays prismatic structure in the center of the photograph could be confused with Inoceramus sp., of Mesozoic age. Small bryozoan fragments are also common in this thin section.

Structures similar to Zoophycos sp. of Häntzchel (1962, p. W219, fig. 137), the so-called Spirophyton sp. of various authors, are common in the sandstone unit. They were first noted by Mertie (1930, p. 122) and later described as slump structures by Laudon, Hartwig, Morgridge, and Omernik (1966, fig. 5, at $1,450 \mathrm{ft}$ on their stratigraphic column). The structures are widely distributed in rocks of Pennsylvanian and Permian age in the Yukon Territory (Nelson, 1961b, p. 35), and they are generally accepted to be of organic origin but of uncertain affinity.

Relation to Underlying Nation River Formation

Mertie (1930, p. 120) and Laudon, Hartwig, Morgridge, and Omernik (1966), in the belief that the sandstone unit grades into the underlying Nation River Formation, proposed elaborate structural explanations for the occurrence of the Nation River Formation structurally below the Calico Bluff Formation of Carboniferous age in other areas (see discussion by Brabb and Churkin, 1967). In 1962 Churkin dug out the contact between the oldest beds of the sandstone unit and the youngest beds of the underlying Nation River Formation (fig. 9) and discovered a 6-inch-thick layer of bluish-gray clay that he interpreted to be a paleosol. A fault-gouge origin for this clay was also considered, but no evidence for a fault contact was found. Furthermore, the clay has a uniform texture and does not show any evidence of fracturing or shearing; it is plastic when wet, as are many clay deposits of sedimentary origin. Richard A. Scott analyzed spores and pollen in samples from the clay (D1940C), from the uppermost shale beds of the Nation River F'ormation (D1904B), from the shale about 75 feet below the top of the Nation River Formation (D1904A), and from the shale of the Nation River Formation at several other localities and he determined that the samples are all Devonian. The age and character of the spore assemblage were documented by Scott and Doher (1967). Their report, together with data from regional mapping, formed the basis for the reports by Churkin and Brabb (1965) and Brabb and Churkin (1967) in which the age of the Nation River Formation was revised from Pennsylvanian( ?) to Late Devonian. Inasmuch as the sandstone unit of the Tahkandit is Early Permian, an unconformity representing all the Carboniferous and part of the Upper Devonian and Permian separates the basal beds of the sandstone unit from the top of the underlying Nation River Formation.

The sandstone unit of the Tahkandit has no clay, and it is better sorted and has far more calcite and glauconite than sandstone beds in the underlying Nation River Formation. The nearly ubiquitous occurrence of plant fragments in the Nation River Formation and of brachiopods in the Tahkandit Limestone are even more helpful in distinguishing these rock units.

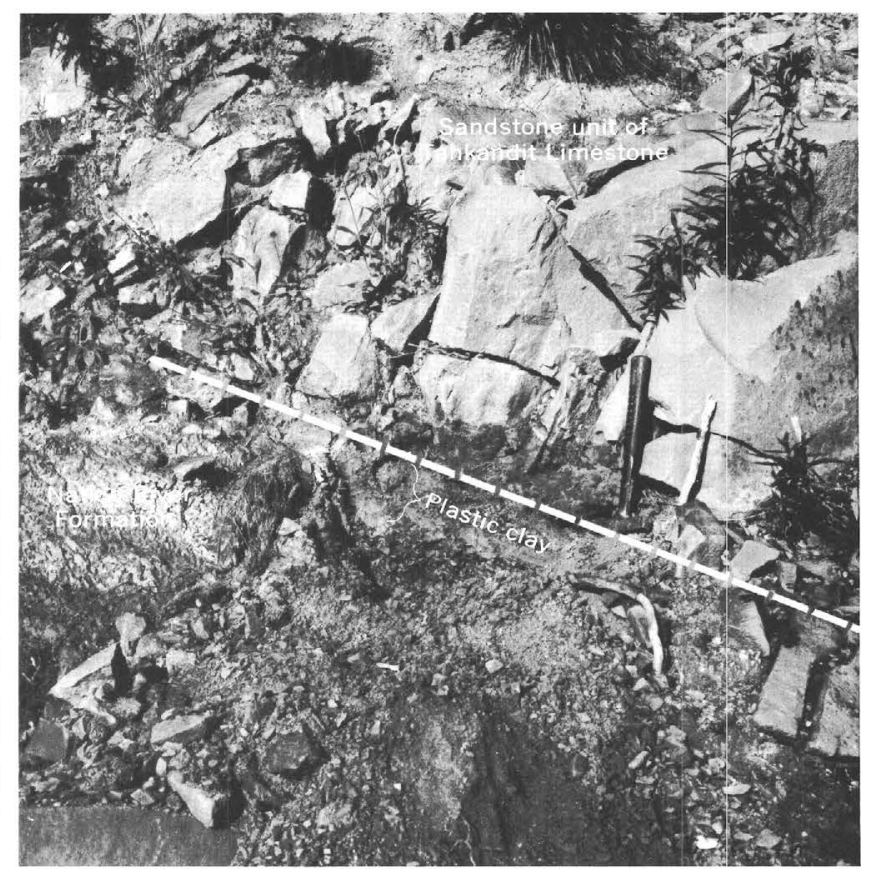

Figure 9.-Contact (dashed line) between the Tahkandit Limestone and the Nation River Formation in the slough section. Plastic clay at the top of the Nation River Formation is probably a paleosol. The clay is underlain by thinly laminated shale. 


\section{LIMESTONE UNIT}

Lithology

The limestone unit consists predominantly of algal, bryozoan, pelmatazoan, foraminiferal, and brachiopod fragments 1-2 $\mathrm{mm}$ in maximum dimension and partly of secondary(?) calcite that has filled the spaces between the fossil fragments. Figures 10 and 11 show the representative texture and lithology. Chert, quartz, and glauconite grains are minor but pervasive constituents. Rapid rock analyses of three samples (loc. 21749-PC, 21747-PC, and 22325-PC) from the limestone show that the $\mathrm{CaO}$ plus $\mathrm{CO}_{2}$ content is $96.2,96.3$, and 96.6 percent respectively, and that the $\mathrm{MgO}$ content is less than 1 percent. Acid insoluble residues of several additional limestone samples help confirm that the limestone unit is nearly pure calcium carbonate.

No bedding was observed in the limestone, but there are several widely spaced and parallel partings that could be an expression of subtle changes in lithology or, more likely, sheeting joints parallel to bedding. No bedded chert was found in the limestone unit at the type section or at nearly all other exposures, but a few thin beds of pale brown chert were observed at the top of the limestone unit about a mile northeast of the cliff section.

\section{Fossils}

Brachiopods are abundant throughout the limestone unit; they are described in another section of this report. Algal, bryozoan, pelmatazoan, and foraminiferal fragments are common, and at locality

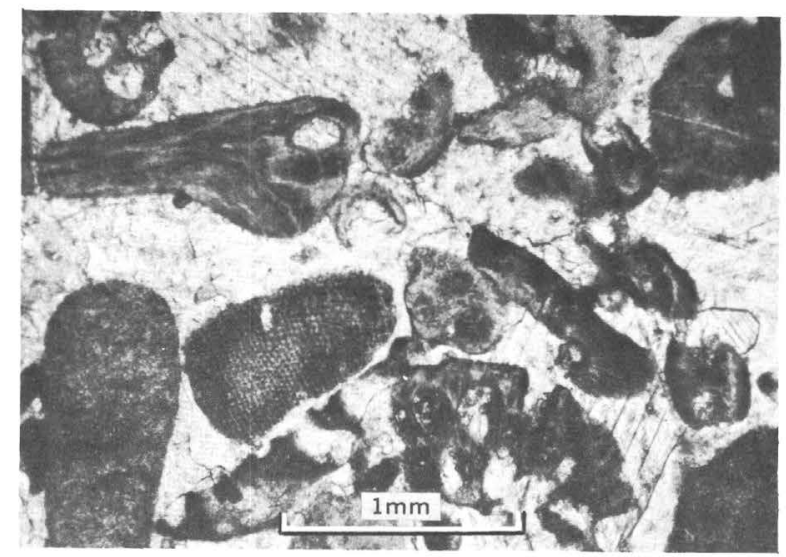

Figure 10.-Photomicrograph of bioclastic limestone in the Tahkandit Limestone (loc. 21760-PC) showing broken and abraded fossils cemented by sparry calcite. The sievelike fragments are parts of echinoderms, and most of the other pieces are parts of bryozoans.
21751-PC arenaceous foraminifers are abundant in insoluble residues of the limestone. A few corals were observed or collected at nearly every locality.

\section{REPEATED SECTION}

The Tahkandit Limestone structurally above the limestone unit near locality 22327-PC in the slough section (see fig. 3 and fig. 5 , $\cdot$ col. 2 ), is considered to be repeated by faulting. This inferred repeated section is shown in figure 5 (col. 3). The idea of a faulted and repeated section is supported by a similar stratigraphic sequence-from sandstone to sandy and glauconitic limestone to fairly pure limestone in both the slough section (col. 2) and the inferred repeated section (col. 3) - and by the similarity of faunas at locality 21794-PC to faunas in the lower part of the limestone unit in the slough and cliff sections.

Tahkandit beds in the upper part of the cliff section (fig. 5, col. 1) are not exposed in the corresponding part of the inferred repeated section. They could be covered by river silt, but it is more likely that these rocks have been faulted above river level and removed by erosion.

\section{CORRELATION OF CLIFF SECTION AND SLOUGH SECTION}

Nearly all the sandstone unit is concealed beneath talus in the cliff section, so it was difficult to determine the stratigraphic position of the cliff section with respect to the slough section. A few sandy and glauconitic limestone and sandstone beds in the vicinity of locality 21746-PC are considered to be

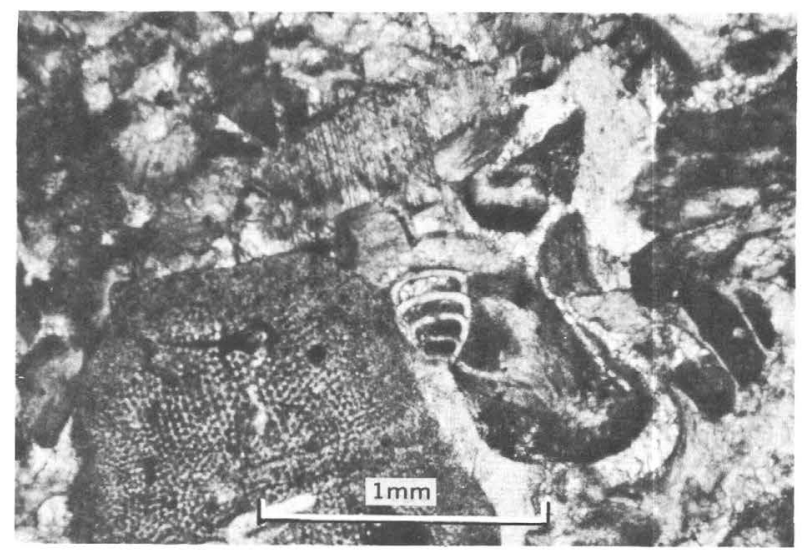

FigURE 11.-Photomicrograph of bioclastic limestone characteristic of the limestone unit of the Tahkandit Limestone (loc. 21748-PC) in the cliff section. The largest sievelike fragment is from an echinoderm, the chambered shell in the center is a foraminifer, and most of the other pieces are from bryozoans. 
uppermost beds of the sandstone unit. They are overlain by a massive, relatively pure limestone like that in the lower part of the limestone unit in the slough section. The sections are correlated, therefore, by similar lithology and similar sequence.

\section{RELATION TO OVERLYING GLENN SHALE}

The Tahkandit Limestone is overlain by the Glenn Shale, a newly named formation of Middle Triassic to Early Cretaceous age (Brabb, 1969, p. 113). In the inferred repeated section (fig. 5, col. 3), however, the oldest fossils that have yet been found in the Glenn Shale are Late Triassic (Norian), according to N. J. Silberling (see Brabb, 1969, p. 112). The contact between the Glenn Shale and Tahkandit Limestone is not exposed wherever the formations have been recognized, so the stratigraphic and structural relations between the formations are uncertain.

\section{THICKNESS}

The composite type section (fig. 5) indicates that the sandstone unit is about 75 feet thick and the limestone unit about 270 feet; thus, the total thickness of the type Tahkandit is about 345 feet. This thickness is substantially less than the 527 feet reported by Mertie (1930, p. 123), but part of his section is considered to be repeated by faulting. The thickness is far less than the 2,065 feet reported by Laudon, Hartwig, Morgridge, and Omernik (1966, fig. 5), but their section includes parts of the Nation River Formation and parts of the Tahkandit repeated by faulting or slumping or both.

\section{SUMMARY}

1. Mertie's (1930) type section for the Tahkandit Limestone is incomplete and faulted. A supplementary section is added to Mertie's section so as to include the entire formation.

2. The type section proposed by Laudon, Hartwig, Morgridge, and Omernik (1966) includes infolded and improperly assigned parts of the underlying Nation River Formation, as well as slumped(?) and faulted parts of the Tahkandit that they interpreted to be a continuous stratigraphic sequence.

3. The total thickness of the Tahkandit is about 345 feet, not the 527 feet reported by Mertie $(1930$, p. 123), nor the 2,065 feet reported by Laudon, Hartwig, Morgridge, and Omernik (1966, fig. 5).
4. An unconformity separates the Tahkandit from the underlying Nation River Formation.

\section{TAHKANDIT LIMESTONE AT OTHER LOCALITIES}

The Tahkandit Limestone has been recognized and mapped in a 900-square-mile area of east-central Alaska, principally in the vicinity of the Nation River and its tributaries (Brabb and Churkin, 1969). In this area it consists of massive, very pale orange or light- to dark-gray limestone containing abundant brachiopods. Glauconite and chert grains are common but not conspicuous.

The thickness of the Tahkandit outside the type section nowhere exceeds 300 feet. At most localities, only a few tens of feet of the formation are exposed.

Brachiopods from the Tahkandit Limestone outside the type section are listed in table 2 . The localities from which these fossils were collected are described on pages 18-21.

\section{BRACHIOPODS FROM THE TAHKANDIT LIMESTONE} AGE

Brachiopods are the most abundant fossils in the Tahkandit Limestone and, in the absence of fusulinids or other fossils convenient for age determination, provide the basis for correlation with other formations in the nearby Yukon Territory (Nelson, 1961a; Ross, 1967; Bamber and Barss, 1969) and elsewhere (this paper). The Tahkandit brachiopods represent an Arctic fauna that permits close correlation with Permian faunas throughout the Arctic, including those of the type Permian of the Soviet Union. They also provide an estimate of the relative age of the fauna in terms of the North American provincial series based on sections in the Southwestern United States.

The brachiopods suggest that the age of the Tahkandit is Early Permian and probably spans the interval from late Leonard to early Guadalupe. In terms of the Texas section, this implies correlation with the Lower Permian Road Canyon and Word Formations (Cooper and Grant, 1966). Arctic Permian brachiopods are long ranging, however, so correlations across such a great distance and span of latitude must be considered approximate at best.

Correlation among Arctic units is somewhat more satisfactory because similar faunas can be compared over shorter distances, although it is still difficult to estimate precise equivalency among faunas consisting of long-ranging species. Correlation with other Arctic units that contain fusulinids or ammonoids provides an alternative method of 
correlation with the Texas section. As will be explained, brachiopods of the sandstone unit of the Tahkandit seem to accord best with those of the Assistance Formation in the Canadian Arctic Archipelago. The Assistance, in turn, is considered to be latest Leonard in age (Nassichuk and others, 1965; Waterhouse, 1968).

Brachiopods from the limestone unit of the Tahkandit indicate a slightly younger age and a closer relationship to the central east Greenland fauna described by Dunbar (1955). This sequence has been previously considered very Late Permian (for example, Permian Subcommittee, 1960; Nassichuk and others, 1965) largely because of presence of the ammonoid Cyclolobus. Dutro (1961) presented a correlation chart for the Arctic Permian, which stated explicitly that the east Greenland beds are not latest Permian. Recent evidence suggests that the range of Cyclolobus begins earlier in the Permian and corroborates the opinion that the east Greenland fauna is older than hitherto believed (Grant, 1968).

The fauna of the limestone unit is certainly not identical with the east Greenland fauna, but it does contain elements of that fauna (as will be explained) that suggest an age slightly younger than that of the sandstone unit of the Tahkandit. On this rather tenuous basis, an early Guadalupe (that is, Word) age is indicated.

The area of Permian outcrop nearest to the Tahkandit type section is in the Ogilvie Mountains, just across the border in the Yukon Territory, Canada (Nelson, 1961a). The best section is on the Tatonduk

TABLE 2.-Brachiopods from the Tahkandit Limestone outside the type section [Stratigraphic position uncertain]

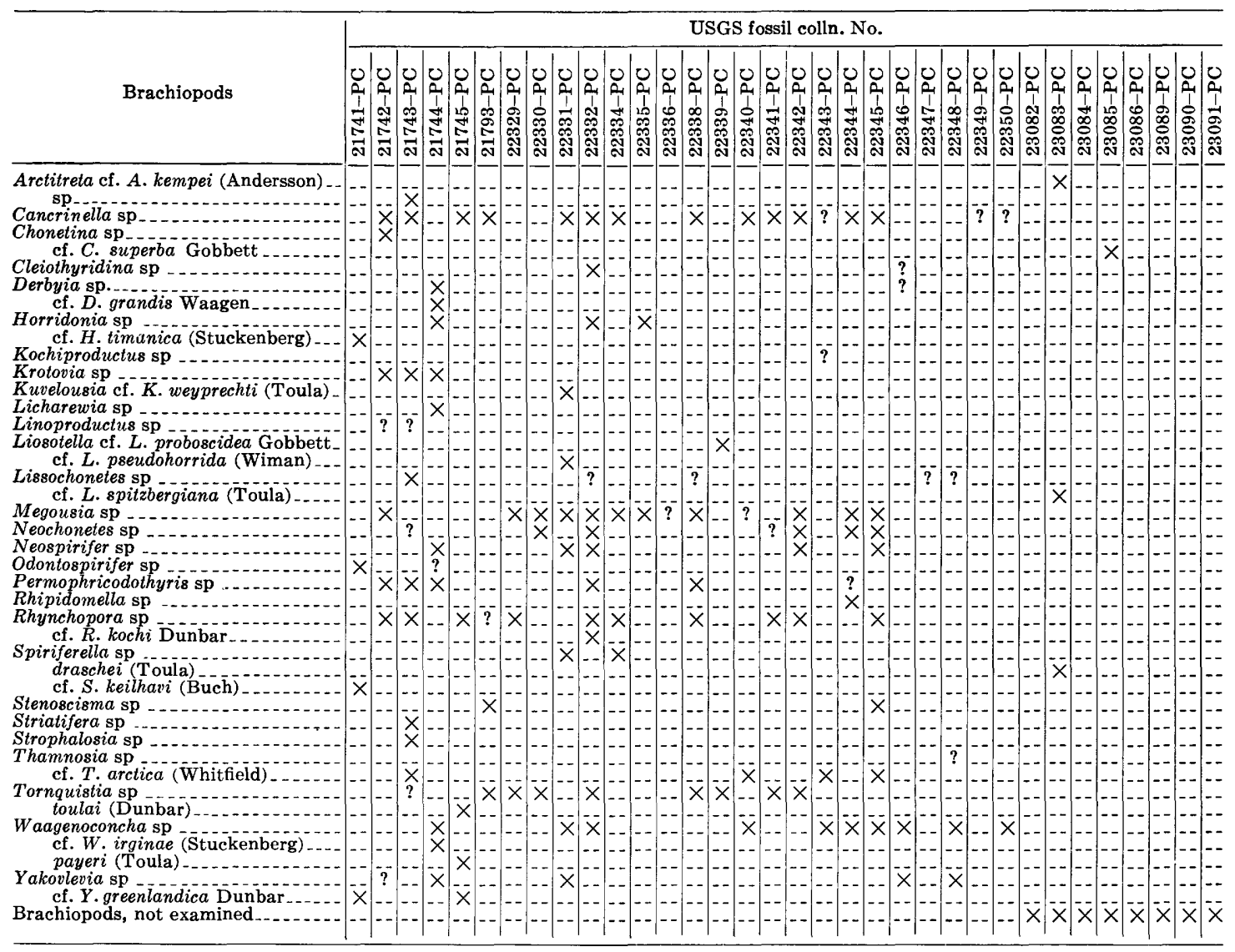


River (see fig. 1), 30 airline miles from Nation, Alaska. This section was described by Bamber and Barss (1969), who applied the name Tahkandit Formation to the uppermost unit; this unit had been dated by Ross (1967) as Leonard in age on the basis of fusulinids from the lower part of the unit. It is tempting to accept the Tahkandit of the Yukon Territory as the direct equivalent of the Tahkandit in Alaska, especially owing to the similar sequencea lower clastic unit and an upper carbonate unit. In detail, however, the sequence in Canada is rather different from the type Tahkandit and much thicker.

The Permian section along the Tatonduk River amounts to about 4,000 feet, and the part called Tahkandit is more than 1,000 feet thick (Bamber and Barss, 1969, p. 5). The glauconitic lower part of the Tahkandit in the Yukon Territory, is 280 feet thick and contains Leonard fusulinids (Bamber and Barss, 1969, p. 6, 7), whereas the sandstone unit of the type Tahkandit is only about 75 feet thick, and no fusulinids have been found in it. The upper unit of the Tahkandit in Canada is mainly chert and dolomite, and only minor amounts of the kind of biogenic limestone that makes up the bulk of the limestone unit in the type section in Alaska are present.

Despite these lithic differences, however, the brachiopod faunas are similar (Nelson, 1961a) and probably correlative. Thus, the Leonard age of the fusulinids in the Canadian rocks equivalent to the lower unit indirectly suggests the age of the type Tahkandit, especially as a Leonard (albeit late Leonard) age is indicated also by the brachiopods for the sandstone unit in the type section.

\section{BRACHIOPODS FROM THE SANDSTONE UNIT}

The lowermost 75 feet of the Tahkandit Limestone -sandstone conglomerate and sandy and glauconitic limestone-contains a brachiopod fauna more similar to that of the Assistance Formation of the Canadian Arctic Archipelago than that of central east Greenland. Brachiopods, some of which are illustrated in this report, are:

Arctitreta cf. A kempei (Andersson)

Calliprotonia? sp.

Cancrinella sp.

Chonetina cf. C. superba Gobbett

Choristites sp.

Cleiothyridina sp.

Craspedalosia sp.

Dielasma cf. D. timanicum (Tschernyschev)

Krotovia sp.

Kuvelousia cf. K. weyprechti (Toula)

Lingula cf. $L$. freboldi Gobbett

Linoproductus sp.

Linoproductus cf. L. schrencki (Stuckenberg)
Liosotella pseudohorrida (Wiman)

Lissochonetes sp.

Martinia sp.

Neochonetes sp.

Odontospirifer sp.

Orbiculoidea sp.

Permophricodothyris cf. P. nodosa (Chao)

Pterospirifer sp.

Rhŷnchopora kochi Dunbar

Spiriferella cf. S. saranae (Verneuil)

Stenoscisma spitzbergiana (Stepanov)

Striatifera sp.

Thamnosia cf. T. arctica (Whitfield)

Tornquistia sp.

Waagenoconcha cf. W. irginae (Stuckenberg)

Yakovlevia mammata (Keyserling)

\section{BRACHIOPODS FROM THE LIMESTONE UNIT}

The upper 270 feet of the Tahkandit Limestonepredominantly white limestone-contains a large brachiopod fauna similar in most respects to that of the lower unit but lacking or nearly lacking some species such as Thamnosia cf. T. arctica and having a few additional species that suggest somewhat closer affinities to the central east Greenland fauna. Kochiproductus and abundant Horridonia and Kuvelousia sphiva indicate a slightly younger age for this part of the Tahkandit Limestone, perhaps correlative to part of the Foldvik Creek Formation of central east Greenland or to one or both of the unnamed formations above the Assistance Formation in the Canadian Arctic Archipelago (Nassichuk and others, 1965; Waterhouse, 1968). Brachiopods from this part of the Tahkandit Limestone, some of which are illustrated in this report, are:

Arctitreta cf. A. kempei (Andersson)

Cancrinella sp.

cf. C. tenuissima Gobbett

Cleiothyridina sp.

Composita cf. C. ambigua (Sowerby)

Derbyia sp.

Horridonia granulifera (Toula)

Hustedia sp.

Kochiproductus sp.

Kuvelousia sphiva Waterhouse

Licharewia sp.

Linoproductus sp.

Liosotella pseudohorrida (Wiman)

Lissochonetes cf. L. spitzbergiana (Toula)

Megousia sp.

Neochonetes sp.

Neospirifer cf. N. striatoparadoxus (Toula)

Odontospirifer sp.

Permophricodothyris sp.

Pterospirifer alatus (Schlotheim)

Rhynchopora kochi Dunbar

Septacamera cf. S. kutorgae (Tschernyschev)

Spiriferella draschei (Toula)

Stenoscisma sp. 
Tornquistia sp.

Waagenoconcha cf. W. irginaeformis (Stepanov)

Yakovlevia mamnata (Keyserling)

The brachiopods that are illustrated (pls. 1 and 2) are discussed briefly below, in the order of the Treatise on Invertebrate Paleontology, part $\mathrm{H}$, (Moore, 1965). Suprageneric categories are given only to provide the reader with necessary clues for easy recognition of the group to which each species belongs; the genera are arranged alphabetically within each of these categories.

\section{SYSTEMATIC PALEONTOLOGY}

Family SCHUCHERTELLIDAE Williams, 1953 Genus ARCTITRETA Whitfield, 1908

Arctitreta cf. A. kempei (Andersson) Plate 2, figures 21, 22, 25

Species of this streptorhynchoid brachiopod are common in many Arctic Permian faunas. Wiman (1914), for example, devoted several plates to illustrations of shells of this type (which he designated as species of Streptorhynchus) from Spitsbergen and indicated that they are extremely abundant there. The common type having the wide hinge is A. kempei, similar to the very few specimens that have been found in the limestone unit of the Tahkandit Limestone.

The name Arctitreta has remained essentially unused since it was proposed by Whitfield (1908) for the poorly preserved species $A$. pearyi from Cape Sheridan, Ellesmere Island. More recently, the name Grumantia was proposed by Ustritskii (in Ustritskii and Chernyak, 1963, p. 70) for Streptorhynchus kempei, a well-documented species whose interior features are known. Study of Whitfield's figures and plaster casts of the types of $A$. pearyi, however, against the background of some familiarity with Arctic Permian brachiopods, leaves very little doubt that the genus Arctitreta encompasses "Grumantia" kempei. A. pearyi probably is conspecific with Streptorhynchus triangularis Wiman.

\section{Family CHONETIDAE Bronn, 1862 Genus CHONETINA Krotov, 1888 \\ Chonetina? cf. C. superba Gobbett Plate 1 , figure 37}

This large chonetid resembles the one illustrated by Gobbett (1963, pl. 15, fig. 2-6) from the Brachiopod Chert of Svalbard in its large size, quadrate outline, very weakly costellate surface, and shallow sulcus. From all accounts, however, these shells bear little resemblance to $C$. artiensis Krotov, the type species (see for example, Muir-Wood, 1962, pl. 5, fig.
9-12 for illustrations of the type). These large chonetids are fairly common in the sandstone unit of the Tahkandit Limestone.

Genus LISSOCHONETES Dunbar and Condra, 1932

Lissochonetes of. L. spitzbergiana (Toula)

Plate 2, figures 15-17

This is one of several chonetids in the Tahkandit Limestone. It is characterized by a tiny and entirely smooth shell having a shallow median fold. It occurs in the upper unit of the formation, along with a very large species of Chonetina? (pl. 1, fig. 37). Another chonetid, not illustrated here, intermediate in size between $L$. cf. L. spitzbergiana and Chonetina? cf. $C$. superba and having the faint costellation of a species of Neochonetes, is locally very abundant in the glauconitic beds of the sandstone unit.

Superfamily PRODUCTACEA Gray, 1840 Genus THAMNOSIA Cooper and Grant, 1969

Thamnosia cf. T. arctica (Whitfield)

Plate 1, figures 37-39, 45

This large productid is one of the more common brachiopods in Arctic Permian faunas and is similarly abundant in the Tahkandit Limestone. It has been placed in several genera since Whitfield (1908) designated it as a species of Productus. Gobbett (1963, p. 91) assigned it to Costiferina MuirWood and Cooper, but it seems to have little in common with $C$. indica (Waagen), the type species. Cooper and Grant (1969, p. 10) established the genus Thamnosia for a group of species from the Leonard and Word Formations that includes forms closely similar to the Arctic shells. The specific name is applied tentatively because it is suspected that the name "arctica" included more than one species, but no comparative study was undertaken to confirm this. This species occurs in both units of the Tahkandit but seems to be limited to the sandstone unit and only the lower part of the limestone unit.

\section{Genus CANCRINELLA Frederiks, 1928}

Cancrinella sp. undet.

Plate 1, figures 31,32 ; plate 2, figures 18,19

One or more species of Cancrinella are present but not particularly abundant in most collections from both units of the Tahkandit. Some beds in the sandstone unit have considerable accumulations of these shells; for example, the silty limestone bed 66 feet above the base that contains the two specimens illustrated on plate 1 is essentially a Cancrinella coquinite. 
Genus HORRIDONIA Chao, 1927

Horridonia granulifera (Toula)

Plate 1, figures 46,47

Productus horridus Sowerby var. granuliferus Toula, 1875, p. 232 , pl. 6 , fig. 3a-c.

Horridonia timanica Gobbett (not Stuckenberg), 1963, p. 94, pl. 10, fig. 1-4.

Horridonia granulifera (Toula) Logan, 1966, p. 206, fig. 2 (for discussion and full synonymy).

Horridonia is one of the characteristic brachiopods of the Arctic Permian and probably for that reason has been split into many species. Logan (1966) presented an analysis of Horridonia and combined many of the species. His interpretation of the common Arctic Horridonias is followed here: $H$. granulifera lacks cardinal and auricular spines on the ventral valve.

Horridonia granulifera is abundant in the Tahkandit Limestone, except in the lower part of the sandstone unit. It is especially abundant just above the sandstone unit, in the basal part of the limestone unit where some beds are Horridonia coquinites.

Genus LIOSOTELLA Cooper, 1953

Liosotella pseudohorrida (Wiman)

Plate 1, figures $1-5,18-20$

Productus pseudohorridus Wiman, 1914, p. 74, pl. 17, fig. 1-11.

Liosotella pseudohorrida (Wiman) Gobbett, 1963, p. 62, pl. 3, fig. 27-34 (for full synonymy).

The name of this species is well chosen, because at first glance it resembles a very small example of Horridonia. It is characterized by a deep sulcus in the ventral valve and rather sharp ventral flanks, especially on exfoliated specimens. The ventral beak is sharply pointed and costation is very weak; the beak is smooth, lacks rugae, and the costae are weakest there. There are only a few spines; one on each side of the venter, two or three on each flank proximal to the ears, and some small spine bases along the margin that may be the remnants of juvenile attachment spines. This also is one of the more abundant brachiopods in the Tahkandit Limestone; it occurs in both units.

\section{Genus KUVELOUSIA Waterhouse, 1968}

Kuvelousia sphiva Waterhouse

Plate 2, figures 1-4, 11, 25

Kuvelousia sphiva Waterhouse, 1968, p. 1175, pl. 154, fig. 14-20; pl. 155, fig. 1-21.
This species is larger and smoother than either Kuvelousia cf. $K$. weyprechti (Toula) or species of Megousia in the Tahkandit Limestone. The ornamentation consists of weak costellae and growth lines; the sulcus is fairly deep, and the shell outline is somewhat quadrate. The dorsal valve is thick, especially toward the anterior margin, and the extended ears are rather wide and blunt in contrast to the slender ear extensions in Megousia. This is one of the most abundant brachiopods in the limestone unit of the Tahkandit.

\section{Kuvelousia cf. K. weyprechti (Toula) Plate 1, figure 21}

This species is smaller, wider, and more strongly costate than $K$. sphiva. The sulcus of the ventral valve is variable-as deep as in $K$. sphiva in some specimens and very shallow in others. This shell most nearly resembles those assigned to $K$. weyprechti by such authors as Wiman (1914), Frebold (1937), and Gobbett (1963), but full study of the fauna is necessary before it can be identified confidently.

Genus MEGOUSIA Muir-Wood and Cooper, 1960

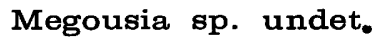

This species is larger than the type species of Megousia from Texas but nevertheless is a rather small shell. It is smaller and proportionately somewhat wider than species of Kuvelousia, but its main distinction is its thin and flexuous dorsal valve with longer and narrower ears than in Kuvelousia. It is fairly common throughout the formation but is not so abundant as Kuvelousia.

\section{Genus LINOPRODUCTUS Chao, 1927}

Linoproductus cf. L. schrencki (Stuckenberg)

Plate 1, figures 40,41

Specimens of Linoproductus are common throughout the Tahkandit Limestone, but they are largest and most abundant in the sandstone unit. A large species having a wide hinge and tapered anterior margin resembles $L$. schrencki in these features, although it differs in lacking the anterior fold or swelling of the ventral valve that is so obvious in L. schrencki (see Tschernyschev, 1902, pl. 27, fig. 1; Ustritskii and Chernyak, 1963, pl. 12, fig. 4-7). This species lacks the flattened or squarish ventral visceral area of so many species of Linoproductus, such as L. dorotheevi (Frederiks) in Gobbett (1963, pl. 11, fig. 2). 
Genus WAAGENOCONCHA Chao, 1927

Waagenoconcha cf. W. irginae (Stuckenberg)

Plate 1, figures $42-44$

This species is characterized by normal convexity for a species of Waagenoconcha, in contrast to the very flat form that has been designated $W$. cf. $W$. irginaeformis (Stepanov). In addition, it is narrower than that species and has a deeper sulcus that is expressed as a fold in the dorsal valve, whereas in $W$. cf. W. irginaeformis the sulcus of the ventral valve is so shallow that it is expressed only as a slight emargination of the dorsal valve. This species occurs in the sandstone unit of the Tahkandit Limestone.

Waagenoconcha of. W. irginaeformis (Stepanov) Plate 2, figures 23,24

This proportionately flat and wide species is rather rare in the limestone unit of the Tahkandit, but a few valves or identifiable fragments occur in most collections. It is not very similar to Stepanov's (1937, pl. 6, fig. 4, 5) species (also illustrated by Tschernyschev, 1902, pl. 52, fig. 2-4), but the name is employed here simply for contrast with the more typical form of Waagenoconcha exemplified by $W$. cf. W. irginae.

Genus YAKOVLEVIA Frederiks, 1925

Yakovlevia mammata (Keyserling)

Plate 1, figures 9-12, 33-36

Productus mammatus Keyserling, 1846, p. 206, pl. 4, fig. 5a-b.

Muirwoodia mammata (Keyserling) Gobbett, 1963, p. 112, pl. 13, fig. 23-28 (for full synonymy).

The very sharp geniculation of the ventral valve distinguishes this species from most other species of Yakovlevia, such as Y. impressa (Toula), Y. duplex (Wiman), or $Y$. greenlandica (Dunbar). It has the four spines that characterize the genus (formerly known as Muirwoodia) : one projects posterolaterally on each ear, and one diverges anteriorly from the other on each anterior surface. Most specimens have only the bases of these spines.

This is one of the most common and typical brachiopods of the Tahkandit Limestone. It occurs in both units throughout the section.
Order RHYNCHONELLIDA Kuhn, 1949 Superfamily RHYNCHONELLACEA Gray, 1848 Family TETRACAMERIDAE Likharev, 1958 Genus SEPTACAMERA Stepanov, 1937

Septacamera cf. S. kutorgae (Tschernyschev)

Plate 2, figure 20

Species of Septacamera are found in most Arctic Permian formations and are abundant in some. Septacamera is very rare in the Tahkandit Limestone but is mentioned here to document its occurrence as a consistent member of the Arctic Permian fauna.

Superfamily STENOSCISMATACEA Oehlert, 1887 Genus STENOSCISMA Conrad, 1839

Stenoscisma spitzbergiana (Stepanov)

Plate 2, figures 29-33

Camerophoria spitzbergania Stepanov, 1937, p. 157, 182, pl. 9, fig. 11; Gobbett, 1963, p. 125, pl. 16, fig. 4-9.

Camerophoria biplicata Frebold (not Stuckenberg), 1950, p. 67, pl. 16, fig. 3-3a.

Stenoscismataceans are abundant in most Arctic Permian faunas but are rare in the Tahkandit Limestone. This species has the shape and costation of Stepanov's species from Spitsbergen, in contrast to $S$. kochi Dunbar or the other species from east Greenland identified by Dunbar (1955). The salient features are the trigonal outline, subdued convexity, three prominent costae on the fold, and weak costae on the flanks. Stenoscisma is in both units of the Tahkandit Limestone.

\section{Superfamily RHYNCHOPORACEA Muir-Wood, 1955 \\ Genus RHYNCHOPORA King, 1865}

Rhynchopora cf. R. kochi Dunbar

Plate 1, figures 22-26

Rhynchopora kochi Dunbar, 1955, p. 114, pl. 19, fig. 7-24.

Rhynchopora is ubiquitous in Arctic Permian faunas. The Tahkandit shells most nearly resemble Dunbar's species from east Greenland in size, shape, and costation although, as Harker and Thorsteinsson $(1960$, p. 64) remarked, that species is very close to R. nikitini var. arctica Likharev and Einor (1939). The Tahkandit shells have the weaker costation that characterizes $R$. kochi; it is fairly abundant throughout the section, and there are at least a few specimens in nearly every sample. 
Order SPIRIFERIDA Waagen, 1883 Superfamily SPIRIFERACEA King, 1846 Genus NEOSPIRIFER Frederiks, 1919

Neospirifer cf. N. striatoparadoxus (Toula) Plate 2, figures 12-14

This is the common form that most workers in the Arctic Permian designate under the name "Spirifer." Its fasciculate costation distinguishes it as a species of Neospirifer, a genus ubiquitous in the Permian. It is a consistent but nowhere abundant constituent of both units of the Tahkandit Limestone.

Genus SPIRIFERELLA Tschernyschev, 1902

Spiriferella draschei (Toula)

Plate 2, figures $26-28,34,35$

Spirifer draschei Toula, 1875, p. 239, pl. 7, fig. 4a-c.

Spiriferella draschei (Toula) Gobbett, 1963, p. 154, pl. 20, fig. 7 (for full synonymy).

Species of Spiriferella are abundant in most Arctic Permian faunas, and the Tahkandit fauna is no exception. Large shells and separated valves make up coquinites in some beds in the upper unit, and the genus also is abundant in the lower unit. Some samples, however, lack Spiriferella entirely, so its occurrence must be considered sporadic despite its great local abundance. More than one species occurs in the Tahkandit Limestone, but only two are illustrated as examples. This one accords very well with Toula's (1875, pl. 7, fig. 4a-c) and Wiman's (1914, pl. 3, fig. 2-26) illustrations of $S$. draschei from Spitsbergen and Bear Island.

Spiriferella of. S. saranae (Verneuil)

Plate 1, figures 13-17

A complete juvenile shell is illustrated as an example of a species of Spiriferella other than $S$. draschei; it most nearly resembles shells that normally are assigned to $S$. saranae, for example by Tschernyschev and Stepanov (1916), Likharev and Einor (1939), Harker and Thorsteinsson (1960), and Gobbett (1963). It has proportionately broader and fewer costae than $S$. draschei, is less strongly convex, and has only a few costae in the sulcus rather than the abundantly costate sulcus of $S$. draschei.
Family RETICULARIACEA Waagen, 1883 Genus MARTINIA M'Coy, 1844

Martinia sp. undet.

Plate 1, figures 27-30

Examples of Martinia, rare in the Tahkandit Limestone, have been found only in the sandstone unit. This smooth and empty shell apparently lacks a fold and thus is different from $M$. greenlandica Dunbar, which is abundant in the east Greenland fauna. It most nearly resembles Martinia sp. A of Gobbett (1963, pl. 21) from the Lower Gypsiferous Series of Svalbard. That series is Carboniferous in age, so the resemblance probably results from the essential featurelessness of these shells.

Genus PERMOPHRICODOTHYRIS Pavlova, 1965 Permophricodothyris cf. P. nodosa (Chao)

Plate 1, figures $6-8$

This species is characterized by its rather strong convexity, proportionately long dorsal beak, and its distinct and regularly spaced growth laminae that are fringed by the bases of tiny spines and set off from one another by a very shallow groove around the anterior edge of each lamina. Of described species it most nearly resembles Squamularia nodosa Chao (1929, p. 95, pl. 11, fig. 4-6) from the Loping Series of Kiangsi, China.

The name Permophricodothyris was introduced by Pavlova (1965, p. 133) for Permian shells that previously had been called Neophricadothyris Likharev, a genus that she considers synonymous with Phricodothyris George. Permophricodothyris (this or other species) is not abundant in the Tahkandit Limestone, but most samples have a few specimens. It occurs in both units.

LOCALITY DESCRIPTIONS FOR PERMIAN FOSSIL COLLECTIONS FROM EAST-CEN'TRAL ALASKA

The identification and location of Permian fossils collected in east-central Alaska prior to 1937 were published by Mertie (1930, p. 125-129 ; 1933, p. 431$432 ; 1937$, p. 148-152). More recent collections of Permian fossils from the Step Conglomerate, a lateral facies of the Tahkandit Limestone in the upper Nation River area, were identified by R. E. Grant and listed by Brabb (1969, p. 19). Table 3 completes the description of Permian fossil localities between the abandoned settlement of Nation (see fig. 1) and the United States-Canada boundary. 
TABLE 3.-Locality descriptions for Permian fossil collections from east-central Alaska

\begin{tabular}{cccc}
\hline $\begin{array}{c}\text { USGS fossil } \\
\text { colln. No. }\end{array}$ & $\begin{array}{c}\text { USGS field } \\
\text { loc. No. }\end{array}$ & Description of locality & $\begin{array}{c}\text { Stratigraphic position } \\
\text { and lithology }\end{array}$ \\
\hline
\end{tabular}

\section{Slough section}

[Charley River A-2 quad., 1956 ed. All fossils from Tahkandit Limestone in place; listed in stratigraphic order from oldest to youngest, unless otherwise noted]

\begin{tabular}{|c|c|c|c|c|c|}
\hline 21752-PC & $\ldots \ldots \ldots \ldots 60 \mathrm{ABa} 672 \mathrm{~A}$ & $\begin{array}{r}\text { Lat } 65^{\circ} 10.8^{\prime} \\
\text { southwest } \\
\text { along slou }\end{array}$ & $\begin{array}{l}\text { N., long } 141^{\circ} 41.9^{\prime} \mathrm{W} . \text {; } \\
\text { bank of Yukon River } \\
\text { agh. }\end{array}$ & $\begin{array}{l}\text { About } 5 \mathrm{ft} \text { stratigraphically above } \\
\text { base of sandstone unit; from } \\
\text { fine-grained sandstone. }\end{array}$ & H. J. Roepke, 1960. \\
\hline 21769-PC & $\ldots \ldots \ldots \ldots 60$ ABa672B & $\ldots \ldots \ldots \ldots$ & ...do..... & $\begin{array}{l}\text { About } 2 \mathrm{ft} \text { above } 60 \mathrm{ABa} 672 \mathrm{~A} \text {; from } \\
\text { pebbly sandstone. }\end{array}$ & Do. \\
\hline 21753-PC & $\ldots \ldots \ldots \ldots \ldots 6 \mathrm{ABa} 672 \mathrm{C}$ & $\ldots \ldots \ldots \ldots$ & ...do.... & $\begin{array}{l}\text { About } 7 \mathrm{ft} \text { above } 60 \mathrm{ABa} 672 \mathrm{~B} \text {; from } \\
\text { glauconitic sandstone. }\end{array}$ & Do. \\
\hline 21795-PC & $\ldots \ldots \ldots \ldots \ldots 6 \mathrm{ABa} 672 \mathrm{CE}$ & B $\ldots \ldots \ldots \ldots$ & ....do.... & $\begin{array}{l}\text { About } 17 \mathrm{ft} \text { above base of sand- } \\
\text { stone unit. }\end{array}$ & $\begin{array}{l}\text { Michael Churkin, Jr., } \\
1963 .\end{array}$ \\
\hline 21754-PC & $\ldots \ldots \ldots \ldots 60 \mathrm{ABa} 672 \mathrm{D}$ & $\cdots \ldots \ldots \ldots$ & $\ldots$. do.... & $\begin{array}{l}\text { About } 7 \text { ft above } 60 \mathrm{ABa} 672 \mathrm{C} \text {; be- } \\
\text { neath a 1-ft-thick chert-pebble } \\
\text { conglomerate bed; from glauco- } \\
\text { nitic sandstone. }\end{array}$ & H. J. Roepke, 1960 . \\
\hline 23046-PC & $\ldots \ldots \ldots \ldots 67 \mathrm{~A} 2+22$ & $\cdots \cdots \cdots \cdots \cdots$ & ... do.... & $\begin{array}{l}\text { Close to } 60 \mathrm{ABa} 672 \mathrm{D} \text {; about } 22 \mathrm{ft} \\
\text { above base of sandstone unit. }\end{array}$ & $\begin{array}{l}\text { R. E. Grant, E. W. } \\
\text { Bamber, A. K. Arm- } \\
\text { strong, and E. E. } \\
\text { Brabb, 1967. }\end{array}$ \\
\hline 21796-PC & $\ldots \ldots \ldots \ldots \ldots 63 \mathrm{ACn} 2331$ & $\ldots \ldots \ldots \ldots \ldots$ & ....do.... & $\begin{array}{l}\text { About } 8 \mathrm{ft} \text { stratigraphically above } \\
60 \mathrm{ABa} 672 \mathrm{D} \text { and } 29 \mathrm{ft} \text { above base } \\
\text { of sandstone unit; from sand- } \\
\text { stone. }\end{array}$ & $\begin{array}{l}\text { Michael Churkin, Jr., } \\
\text { 1963. }\end{array}$ \\
\hline 23047-PC & $\ldots \ldots \ldots \ldots \ldots 67 \mathrm{~A} 2+40$ & n.m. & ....do.... & $\begin{array}{l}\text { About } 40 \mathrm{ft} \text { above base of sand- } \\
\text { stone unit. }\end{array}$ & $\begin{array}{l}\text { R. E. Grant, E. W. } \\
\text { Bamber, A. K. Arm- } \\
\text { strong, and E. E. } \\
\text { Brabb, 1967. }\end{array}$ \\
\hline 21755-PC & $\ldots \ldots \ldots \ldots, 60 \mathrm{ABa} 672 \mathrm{E}$ & $\ldots \ldots \ldots \ldots$ & ...do.... & $\begin{array}{l}\text { About } 44 \mathrm{ft} \text { above base of sand- } \\
\text { stone unit. }\end{array}$ & H. J. Roepke, 1960. \\
\hline 21797-PC & $\ldots \ldots \ldots \ldots \ldots 6 \mathrm{ABa} 672 \mathrm{E}$ & $\cdots \ldots \ldots \ldots$ & ...do.... & Additional material. & $\begin{array}{l}\text { Michael Churkin, Jr., } \\
1963 .\end{array}$ \\
\hline 23048-PC & $\cdots \cdots \cdots \cdots 67 \mathrm{~A} 2+45$ & $\cdots \cdots \cdots \cdots \cdots$ & ...do.... & $\begin{array}{l}\text { Close to } 60 \mathrm{ABa} 672 \mathrm{E} \text {, about } 45 \mathrm{ft} \\
\text { above base of sandstone unit. }\end{array}$ & $\begin{array}{l}\text { R. E. Grant, E. W. } \\
\text { Bamber, A. K. Arm- } \\
\text { strong, and E. E. } \\
\text { Brabb, 1967. }\end{array}$ \\
\hline 23049-PC & 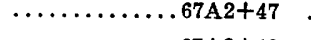 & $\cdots \cdots \cdots \cdots \cdots$ & ...do.... & $2 \mathrm{ft}$ above $67 \mathrm{~A} 2+45$ & Do. \\
\hline $23050-P C$ & $\ldots \ldots \ldots \ldots 67 \mathrm{~A} 2+49$ & $\cdots \cdots \cdots \cdots \cdots$ & ...do.... & $2 \mathrm{ft}$ above $67 \mathrm{~A} 2+47$ & Do. \\
\hline 23051-PC & $\ldots \ldots \ldots \ldots \ldots 67 \mathrm{~A} 2+53$ & (n.......... & ...do.... & $\begin{array}{l}4 \mathrm{ft} \text { above } 67 \mathrm{~A} 2+49 \text {; near or at } \\
60 \mathrm{ABa} 672 \mathrm{~F} \text {. }\end{array}$ & Do. \\
\hline 21756-PC & $\ldots \ldots \ldots \ldots \ldots 60 \mathrm{ABa} 672 \mathrm{~F}$ & $\cdots \cdots \cdots \cdots$ & ....do.... & $\begin{array}{l}\text { About } 53 \mathrm{ft} \text { above base of sand- } \\
\text { stone unit. }\end{array}$ & H. J. Roepke, 1960. \\
\hline 21798-PC & $\ldots \ldots \ldots \ldots \ldots 60 \mathrm{ABa} 672 \mathrm{~F}$ & $\cdots \ldots \ldots \ldots$ & ...do.... & Additional material. & $\begin{array}{l}\text { Michael Churkin, Jr., } \\
1963 .\end{array}$ \\
\hline 21799-PC & $\ldots \ldots \ldots \ldots 63 \mathrm{ACn} 2332$ & $\cdots \cdots \cdots \cdots$ & ....do.... & About $4 \mathrm{ft}$ above $60 \mathrm{ABa} 672 \mathrm{~F}$ & Do. \\
\hline 21757-PC & $\ldots \ldots \ldots \ldots 60 \mathrm{ABa} 672 \mathrm{G}$ & $\ldots \ldots \ldots \ldots$ & ...do.... & $\begin{array}{l}\text { About } 59 \mathrm{ft} \text { above base of sand- } \\
\text { stone unit. }\end{array}$ & H. J. Roepke, 1960. \\
\hline 22322-PC & $\ldots \ldots \ldots \ldots 60 \mathrm{ABa} 672 \mathrm{G}$ & $\cdots \cdots \cdots \cdots$ & ....do.... & Additional material. & $\begin{array}{l}\text { Michael Churkin, Jr., } \\
\text { 1963. }\end{array}$ \\
\hline 23052-PC & $\ldots \ldots \ldots \ldots \ldots 67 \mathrm{~A} 2+60$ & $\cdots \cdots \cdots \cdots \cdots$ & ...do.... & $60 \mathrm{ft}$ above base of sandstone unit. & $\begin{array}{l}\text { R. E. Grant, E. W. } \\
\text { Bamber, A. K. Arm- } \\
\text { strong, and E. E. } \\
\text { Brabb, 1967. }\end{array}$ \\
\hline 21758-PC & $\ldots \ldots \ldots \ldots \ldots 60 \mathrm{ABa} 672 \mathrm{H}$ & $\ldots \ldots \ldots \ldots$ & $\ldots$. do.... & $\begin{array}{l}\text { About } 65 \mathrm{ft} \text { above base of unit; } \\
\text { from calcareous and glauconitic } \\
\text { sandstone. }\end{array}$ & H. J. Roepke, 1960. \\
\hline 23053-PC & $\cdots \cdots \cdots \cdots \cdots 67 \mathrm{~A} 2+66$ & $\cdots \cdots \cdots \cdots \cdots$ & ....do.... & About $66 \mathrm{ft}$ above base of unit. & $\begin{array}{l}\text { R. E. Grant, E. W. } \\
\text { Bamber, A. K. Arm- } \\
\text { strong, and E. E. } \\
\text { Brabb, } 1967 .\end{array}$ \\
\hline 23054-PC & $\cdots \cdots \cdots \cdots 67 \mathrm{~A} 2+71$ & n.m. & ....do.... & $\begin{array}{l}\text { About } 71 \mathrm{ft} \text { above base of sand- } \\
\text { stone unit. }\end{array}$ & Do. \\
\hline
\end{tabular}


TABLE 3.-Locality descriptions for Permian fossil collections from east-central Alaska-Continued

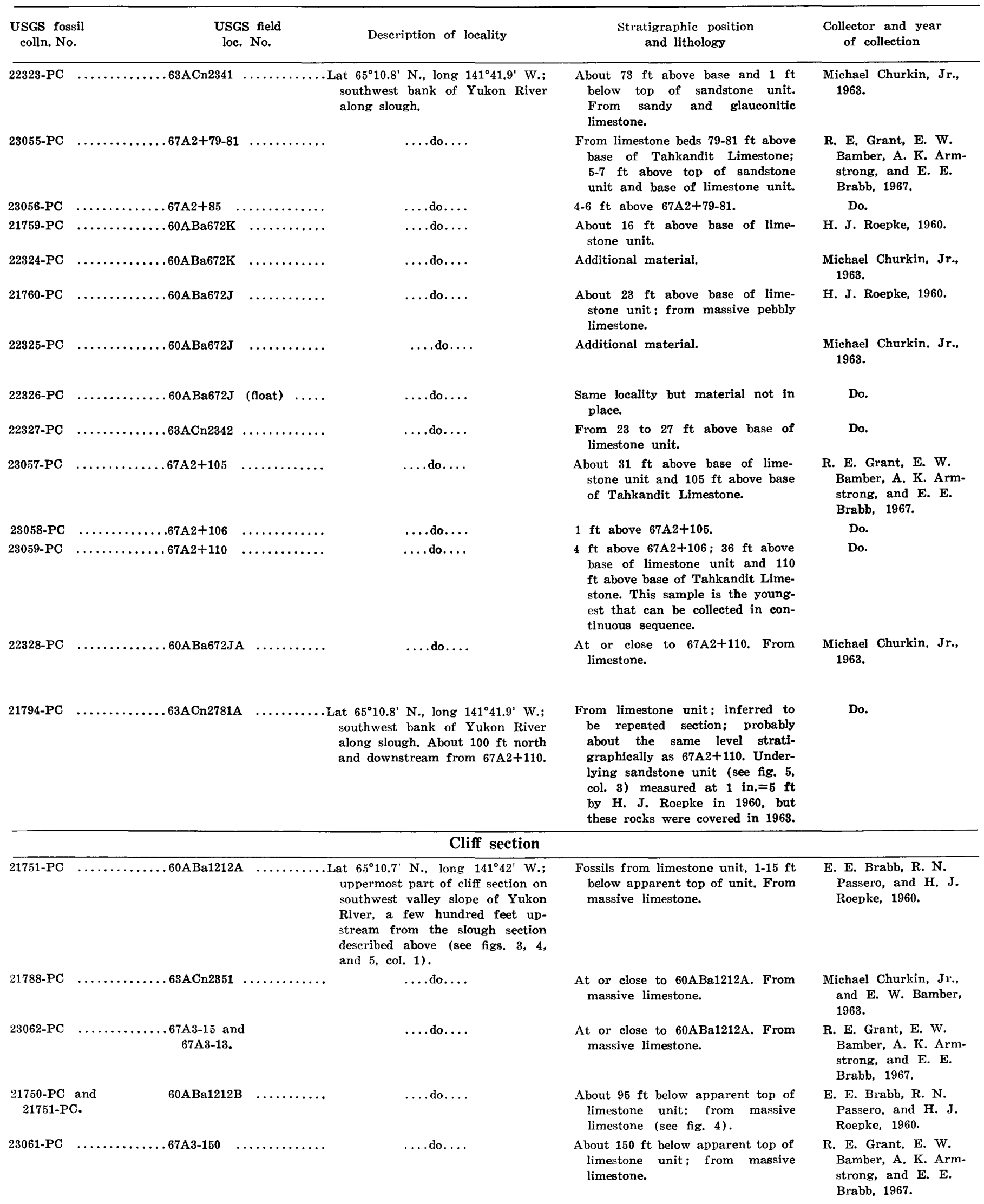


TABLE 3.-Locality descriptions for Permian fossil collections from east-central Alaska-Continued

\begin{tabular}{|c|c|c|c|c|c|}
\hline \multicolumn{3}{|c|}{$\begin{array}{l}\text { USGS fossil } \\
\text { colln. No. }\end{array}$} & Description of locality & $\begin{array}{l}\text { Stratigraphic position } \\
\text { and lithology }\end{array}$ & \multirow{2}{*}{$\begin{array}{l}\begin{array}{l}\text { Collector and year } \\
\text { of collection }\end{array} \\
\text { E. E. Brabb, R. N. } \\
\text { Passero, and H. J. } \\
\text { Roepke, 1960. }\end{array}$} \\
\hline 21749-PC & $\ldots \ldots \ldots \ldots 60 \mathrm{ABa} 1212$ & $2 \mathbf{C} \quad \cdots \cdot$ & $\begin{array}{l}\text {. Lat } 65^{\circ} 10.7^{\prime} \text { N., long } 141^{\circ} 42^{\prime} \text { W.; } \\
\text { uppermost part of cliff section on } \\
\text { southwest valley slope of Yukon } \\
\text { River, a few hundred feet up- } \\
\text { stream from the slough section } \\
\text { described above (see figs. 3, } 4 \text {, } \\
\text { and } 5, \text { col. 1). }\end{array}$ & $\begin{array}{l}\text { About } 160 \mathrm{ft} \text { below apparent top } \\
\text { of limestone unit; from massive } \\
\text { limestone. }\end{array}$ & \\
\hline 21748-PC & $\ldots \ldots \ldots \ldots \ldots 60 \mathrm{ABa} 1212 \mathrm{I}$ & $2 \mathbf{D} \ldots \ldots$ & .. $\quad \ldots$ do. $\ldots$ & $\begin{array}{l}\text { About } 240 \mathrm{ft} \text { below apparent top of } \\
\text { limestone unit; from massive } \\
\text { limestone. }\end{array}$ & Do. \\
\hline 21747-PC & $\cdots \cdots \cdots \cdots 60 \mathrm{ABa} 1212$ & $2 \mathbf{E} \ldots \ldots$ & ....do.... & $\begin{array}{l}\text { About } 265 \mathrm{ft} \text { below apparent top of } \\
\text { limestone unit, from massive } \\
\text { limestone, } 2 \mathrm{ft} \text { above contact with } \\
\text { underlying sandy and pebbly } \\
\text { limestone inferred to be upper- } \\
\text { most beds of sandstone unit. }\end{array}$ & Do. \\
\hline 23060-PC & $\ldots \ldots \ldots \ldots \ldots 67 \mathrm{A3}-265$ & $\cdots \cdots \cdots$ & $\ldots$ do.... & At or close to $60 \mathrm{ABa} 1212 \mathrm{E}$ & $\begin{array}{l}\text { R. E. Grant, E. W. } \\
\text { Bamber, A. K. Arm- } \\
\text { strong, and E. E. } \\
\text { Brabb, 1967. }\end{array}$ \\
\hline 21746-PC & $\ldots \ldots \ldots \ldots 60 \mathrm{ABa} 12121$ & $\cdots \cdots$ & $\ldots$ do.... & $\begin{array}{l}\text { About } 20 \mathrm{ft} \text { stratigraphically be- } \\
\text { low and } 50 \mathrm{ft} \text { north of } 60 \mathrm{ABa}- \\
1212 \mathrm{E} ; 18 \mathrm{ft} \text { below inferred top } \\
\text { of sandstone unit; from sandy } \\
\text { and pebbly limestone and a } 4 \text {-in.- } \\
\text { thick glauconite bed. }\end{array}$ & $\begin{array}{l}\text { E. E. Brabb, R. N. } \\
\text { Passero, and H. J. } \\
\text { Roepke, 1960. }\end{array}$ \\
\hline \multicolumn{6}{|c|}{ Near mouth of Nation River } \\
\hline 23082-PC & $\ldots \ldots \ldots \ldots 67 \mathrm{A4}-200$ & $\cdots \cdots \cdots$ & $\begin{array}{l}\text {.Lat } 65^{\circ} 11.6^{\prime} \mathrm{N} . \text {, long } 141^{\circ} 40.3^{\prime} \mathrm{W} . \text {; } \\
\text { from massive limestone cliffs on } \\
\text { northeast valley slope of Yukon } \\
\text { River. }\end{array}$ & $\begin{array}{l}\text { From limestone unit, visually esti- } \\
\text { mated to be } 200 \mathrm{ft} \text { below appar- } \\
\text { ent top. From massive limestone. }\end{array}$ & $\begin{array}{l}\text { R. E. Grant, E. W. } \\
\text { Bamber, and A. K. } \\
\text { Armstrong, } 1967 \text {. }\end{array}$ \\
\hline 23089-PC & $\ldots \ldots \ldots \ldots 67 \mathrm{ABa} 162$ & $\ldots \ldots$ & .. $\quad \ldots$. do... & Same locality as $67 \mathrm{~A} 4-200$ & E. E. Brabb, 1967 . \\
\hline 23083-PC & $\ldots \ldots \ldots \ldots 667 \mathrm{A4}-200$ & (float) & ...do.... & $\begin{array}{l}\text { Collection from talus in the vicin- } \\
\text { ity of } 67 \mathrm{A4}-200 \text {. Limestone. }\end{array}$ & Do. \\
\hline $\begin{array}{r}23086-\mathrm{PC} \\
23085-\mathrm{PC}\end{array}$ & 67ABa161 & $\ldots \ldots \ldots$ & $\ldots$ do.... & ...do.... & Do. \\
\hline 23084-PC & $\ldots \ldots \ldots \ldots \ldots 67 \mathrm{A4}-250$ & ........ & $\ldots$ do.... & $\begin{array}{l}\text { About } 50 \mathrm{ft} \text { stratigraphically be- } \\
\text { low } 67 \mathrm{A4-200;} \text { from massive } \\
\text { limestone. }\end{array}$ & Do. \\
\hline
\end{tabular}

\section{East of Nation River}

[Charley River B-1 quad., 1956 ed. All fossils from Tahkandit Limestone in place, unless otherwise noted; stratigraphic position uncertain]

\begin{tabular}{|c|c|c|}
\hline 22346-PC & $\ldots \ldots \ldots \ldots \ldots$ 63AGs102 $\ldots \ldots \ldots \ldots \ldots$ Lat $65^{\circ} 17.3^{\prime}$ N., long $141^{\circ} 19.6^{\prime} W$. & From limestone talus. \\
\hline 22345-PC & ............ $65^{\circ} 17.4^{\prime} \mathrm{N}$. long $141^{\circ} 17.1^{\prime} \mathrm{W}$. & From thick-bedded limestone. \\
\hline 22347-PC & $\begin{array}{l}\ldots \ldots \ldots \ldots \text { Lat } 65^{\circ} 19.0^{\prime} \mathrm{N} . \text {, long } 141^{\circ} 12.4^{\prime} \mathrm{W} . ; \\
\text { southwest valley slope of Water- } \\
\text { fall Creek. }\end{array}$ & $\begin{array}{l}\text { From coarse-grained very } \\
\text { orange limestone. }\end{array}$ \\
\hline $22348-P C$ & $\ldots \ldots \ldots \ldots \ldots$ Lat $65^{\circ} 18.8^{\prime}$ N., long $141^{\circ} 11.5^{\prime}$ W. & $\begin{array}{l}\text { From extensively folded and fault- } \\
\text { ed fine-grained gray limestone } \\
\text { along Waterfall Creek. }\end{array}$ \\
\hline 22349-PC & $\begin{array}{c}\ldots \ldots \ldots \text { Lat } 65^{\circ} 18.8^{\prime} \mathrm{N} . \text {, long } 141^{\circ} 11.4^{\prime} \text { W.; } \\
\text { along Waterfall Creek about } 100 \\
\text { ft northeast of } 63 \text { AGs } 124 .\end{array}$ & $\begin{array}{l}\text { From faulted light-colored lime- } \\
\text { stone. }\end{array}$ \\
\hline 22350-PC & $\ldots \ldots \ldots \ldots 6$ 63AGs131B & $\begin{array}{l}\text { From dark-colored limestone and } \\
\text { chert a few feet stratigraphically } \\
\text { below } 63 \mathrm{AGs} 131 \mathrm{~A} \text {. }\end{array}$ \\
\hline 22342-PC & $\begin{array}{c}\ldots \ldots \ldots \ldots \ldots+63 \mathrm{ACn} 1683 \ldots \ldots \ldots \ldots \text { Lat } 65^{\circ} 27.0^{\prime} \mathrm{N} . \text {, long } 141^{\circ} 02.1^{\prime} \mathrm{W} . ; \\
\text { along spur north of Ettrain } \\
\text { Creek. }\end{array}$ & $\begin{array}{l}\text { Near base of pebbly limestone } \\
\text { and chert-pebble conglomerate } \\
\text { mapped as Step Conglomerate by } \\
\text { Brabb and Churkin (1969). }\end{array}$ \\
\hline 22343-PC & $\begin{array}{l}\ldots \ldots \ldots \ldots \text { Lat } 65^{\circ} 27.0^{\prime} \mathrm{N} . \text {, long } 141^{\circ} 02.1^{\prime} \mathrm{W} \text {; } \\
\text { about } 300 \mathrm{ft} \text { north of } 63 \mathrm{ACn} 1683 \text {; } \\
\text { elev about } 2,200 \mathrm{ft} .\end{array}$ & $\begin{array}{l}\text { From limestone and chert-pebble } \\
\text { conglomerate mapped as Step } \\
\text { Conglomerate by Brabb and } \\
\text { Churkin (1969). }\end{array}$ \\
\hline
\end{tabular}

D. L. Giles, 1963 .

E. E. Brabb, 1963.

D. L. Giles, 1963.

Do.

Do.

Do.

Michael Churkin, Jr., 1963.

Do. 
TABLE 3.-Locality descriptions for Permian fossil collections from east-central Alaska-Continued

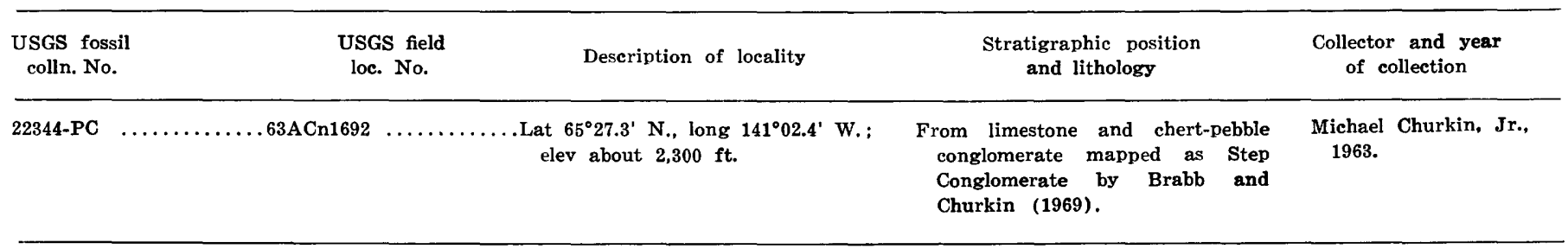

\section{Between Nation and Kandik Rivers}

[Charley River B-1 and B-2 quad., 1956 ed. Fossils all from Tahkandit Limestone, but the formation is so extensively faulted that the stratigraphic position of the collection is uncertain]

\begin{tabular}{|c|c|c|c|c|}
\hline 21742-PC & $\cdots \cdots \cdots \cdots 6 \mathrm{ABa} 561 \mathrm{~A}$ & $\begin{array}{l}\ldots \ldots \ldots \ldots \text { Lat } 65^{\circ} 23.4^{\prime} \mathrm{N} . \text {, long } 141^{\circ} 26.0^{\prime} \mathrm{W} . ; \\
\text { from base of cliff on west valley } \\
\text { slope of Nation River. }\end{array}$ & Thinly bedded dark-gray limestone. & $\begin{array}{l}\text { E. E. Brabb, R. N. } \\
\text { Passero, and H. J. } \\
\text { Roepke, 1960. }\end{array}$ \\
\hline 21745-PC & $\ldots \ldots \ldots \ldots 60$ ABa614 & $\begin{array}{l}\ldots \ldots \ldots \ldots \text { Lat } 65^{\circ} 18.9^{\prime} \mathrm{N} ., \text { long } 141^{\circ} 38.1^{\prime} \mathrm{W} . \text {; } \\
\text { east valley slope of unnamed } \\
\text { tributary to Nation River; elev } \\
\text { about } 1,300 \mathrm{ft} \text {; northernmost of } \\
\text { two limestone spurs. }\end{array}$ & $\begin{array}{l}\text { From thickly bedded olive-gray } \\
\text { limestone. }\end{array}$ & Do. \\
\hline 21744-PC & $\ldots \ldots \cdots \cdots 60 \mathrm{ABa} 614 \mathrm{~A}$ & $\ldots \ldots \ldots \ldots$ Lat $65^{\circ} 18.9^{\prime}$ N., long $141^{\circ} 38.1^{\prime}$ W. & $\begin{array}{l}\text { From more coarsely grained lime- } \\
\text { stone than at } 60 \mathrm{ABa} 614 .\end{array}$ & $\begin{array}{l}\text { E. E. Brabb, R. N. } \\
\text { Passero, and H. J. } \\
\text { Roepke, 1960. }\end{array}$ \\
\hline 21743-PC & $\ldots \ldots \ldots \ldots 60 \mathrm{ABa} 614 \mathrm{~B}$ & $\cdots \cdots \cdots \cdots$ & $\begin{array}{l}\text { About } 15 \mathrm{ft} \text { stratigraphically be- } \\
\text { low } 60 \mathrm{ABa} 614 \mathrm{~A} \text { and } 30 \mathrm{ft} \text { strati- } \\
\text { graphically above the oldest lime- } \\
\text { stone beds exposed. From mas- } \\
\text { sive limestone. }\end{array}$ & Do. \\
\hline 22332-PC & $\ldots \ldots \ldots \ldots \ldots 63 \mathrm{ACn} 2171$ & $\begin{array}{c}\ldots \ldots \ldots \ldots \text { Lat } 65^{\circ} 20.8^{\prime} \mathrm{N} \text {., long } 141^{\circ} 38.7^{\prime} \text { W. ; } \\
\text { elev about } 2,500 \mathrm{ft} \text {. }\end{array}$ & $\begin{array}{l}\text { Near the apparent top of the lime- } \\
\text { stone. }\end{array}$ & $\begin{array}{l}\text { Michael Churkin, Jr., } \\
1963 .\end{array}$ \\
\hline 22331-PC & $\ldots \ldots \ldots \ldots \ldots 6 \mathrm{ACn} 2156$ & $\begin{array}{c}\ldots \ldots \ldots \ldots \text { Lat } 65^{\circ} 20.9^{\prime} \text { N., long } 141^{\circ} 38.9^{\prime} \text { W.; } \\
\text { elev about } 2,200 \mathrm{ft} .\end{array}$ & $\begin{array}{l}\text { Limestone beds here form north } \\
\text { flank of syncline; those at } 63- \\
\text { ACn2171 form south flank. }\end{array}$ & Do. \\
\hline 22340-PC & $\ldots \ldots \ldots \ldots \ldots 63 \mathrm{ACn} 2113$ & $\begin{array}{c}\ldots \ldots \ldots \ldots \text { Lat } 65^{\circ} 20.6^{\prime} \mathrm{N} . \text {, long } 141^{\circ} 43.8^{\prime} \mathrm{W} . ; \\
\text { along crest of ridge; elev about } \\
2,900 \mathrm{ft} \text {. }\end{array}$ & Limestone. & Do. \\
\hline 22329-PC & $\ldots \ldots \ldots \ldots 63 \mathrm{ACn} 2121$ & $\begin{array}{l}\ldots \ldots \ldots \ldots \ldots \text { Lat } 65^{\circ} 20.4^{\prime} \mathrm{N} . \text {, long } 141^{\circ} 43.8^{\prime} \text { W.; } \\
\text { along crest of ridge about } 1,200 \\
\text { ft south of } 63 \mathrm{ACn} 2113 .\end{array}$ & From sandy and pebbly limestone. & Do. \\
\hline $22330-\mathrm{PC}$ & $\ldots \ldots \ldots \ldots 63 \mathrm{ACn} 2124$ & $\begin{array}{l}\ldots \ldots \ldots \ldots \text { Lat } 65^{\circ} 20.2^{\prime} \text { N., long } 141^{\circ} 43.7^{\prime} \text { W.; } \\
\text { about } 1,500 \mathrm{ft} \text { south of } 63 \mathrm{ACn}- \\
2121 .\end{array}$ & $\begin{array}{l}\text { From the top of a 30-ft cliff of } \\
\text { limestone. The limestone beds at } \\
63 \mathrm{ACn} 2113 \text {, 63ACn2121, and 63- } \\
\text { ACn2124 seem to be in repeated } \\
\text { fault slivers separated by argil- } \\
\text { lite of probable Cambrian age. }\end{array}$ & Do. \\
\hline 22334-PC & $\ldots \ldots \cdots \cdots \cdot 63 \mathrm{ACn} 2051$ & $\begin{array}{c}\ldots \ldots \ldots \ldots \ldots \text { Lat } 65^{\circ} 20.0^{\prime} \text { N., long } 141^{\circ} 47.0^{\prime} \text { W. ; } \\
\text { elev about } 2,900 \mathrm{ft} .\end{array}$ & From sandy and pebbly limestone. & Do. \\
\hline 22335-PC & $\cdots \cdots \cdots \cdots \cdots 63 \mathrm{ACn} 2085$ & $\begin{array}{l}\ldots \ldots \ldots \ldots \text { Lat } 65^{\circ} 19.5^{\prime} \mathrm{N} ., \text { long } 141^{\circ} 50.1^{\prime} \text { W.; } \\
\text { elev about } 2,500 \mathrm{ft} .\end{array}$ & From massive limestone. & Do. \\
\hline 22338-PC & $\cdots \cdots \cdots \cdots \cdot 63 \mathrm{ACn} 2131$ & $\begin{array}{c}\ldots \ldots \ldots \ldots \text { Lat } 65^{\circ} 19.8^{\prime} \text { N., long } 141^{\circ} 45.8^{\prime} \text { W.; } \\
\text { elev about } 2,700 \mathrm{ft.}\end{array}$ & From limestone. & Do. \\
\hline 22339-PC & $\ldots \ldots \ldots \ldots+63 \mathrm{ACn} 2132$ & $\begin{array}{c}\ldots \ldots \ldots \ldots \ldots \text { Lat } 65^{\circ} 18.5^{\prime} \mathrm{N} . \text {, long } 141^{\circ} 43.2^{\prime} \text { W. ; } \\
\text { near spot elev } 2,815 \mathrm{ft} .\end{array}$ & ...do..... & Do. \\
\hline $22336-\mathrm{PC}$ & $\ldots \ldots \ldots \ldots 63 \mathrm{ACn} 2143$ & $\begin{array}{c}\ldots \ldots \ldots \ldots \ldots \text { Lat } 65^{\circ} 18.3^{\prime} \mathrm{N} ., \text { long } 141^{\circ} 41.4^{\prime} \text { W.; } \\
\text { elev about } 2,000 \mathrm{ft} .\end{array}$ & From oil-stained limestone. & Do. \\
\hline 22341-PC & $\ldots \ldots \ldots \ldots \ldots 2 \mathrm{ACn} 1072$ & $\ldots \ldots \ldots \ldots$ Same locality as $63 \mathrm{ACn} 2085$ & From massive limestone. & $\begin{array}{l}\text { Michael Churkin, Jr., } \\
1962 .\end{array}$ \\
\hline 21793-PC & $\ldots \ldots \ldots \ldots \ldots 63 \mathrm{ABa} 3832$ & $\begin{array}{c}\ldots \ldots \ldots \ldots \text { Lat } 65^{\circ} 19.3^{\prime} \text { N., long } 141^{\circ} 45.8^{\prime} \text { W.; } \\
\text { elev about } 2,300 \mathrm{ft} .\end{array}$ & From limestone. & E. E. Brabb, 1963 . \\
\hline
\end{tabular}

\section{Miscellaneous locality}

21741-PC $\ldots \ldots \ldots \ldots \ldots 61 \mathrm{ABa} 1881 \ldots \ldots \ldots \ldots$. . . . $65^{\circ} 08.8^{\prime}$ N., long $141^{\circ} 52.3^{\prime}$ W.; Charley River A-2 quad.; south bank of Fourth of July Creek.
From very pale orange Tahkandit Limestone.
E. E. Brabb, J. C. Melik, and R. L. Taylor, 1961. 


\section{REFERENCES CITED}

Bamber, E. W., and Barss, M. S., 1969, Stratigraphy and palynology of a Permian section, Tatonduk River, Yukon Territory: Canada Geol. Survey Paper 68-18, 39 p.

Barss, M. S., 1967, Illustrations of Canadian fossils-Carboniferous and Permian spores of Canada: Canada Geol. Survey Paper 67-11, 94 p.

Brabb, E. E., 1962, Preliminary geologic map of part of the Charley River quadrangle, east-central Alaska: U.S. Geol. Survey open-file report, scale 1:250,000.

1969, Six new Paleozoic and Mesozoic formations in east-central Alaska: U.S. Geol. Survey Bull. 1274-I, p. I1-I26.

Brabb, E. E., and Churkin, Michael, Jr., 1964, Preliminary geologic map of the Charley River quadrangle, eastcentral Alaska: U.S. Geol. Survey open-file report, scale $1: 250,000$.

1965, Preliminary geologic map of the Eagle (D-1) quadrangle, east-central Alaska: U.S. Geol. Survey openfile report, scale 1:63,360.

1967, Stratigraphic evidence for the Late Devonian age of the Nation River Formation, east-central Alaska, in Geological Survey research 1967: U.S. Geol. Survey Prof. Paper 575-D, p. D4-D15.

1969, Geologic map of the Charley River quadrangle, east-central Alaska: U.S. Geol. Survey Misc. Geol. Inv. Map I-573, scale 1:250,000.

Brosgé, W. P., Lanphere, M. A., Reiser, H. N., and Chapman, R. M., 1969, Probable Permian age of the Rampart Group, central Alaska: U.S. Geol. Survey Bull. 1294-B, p. B1-B18.

Chao, Y. T., 1929, Carboniferous and Permian spiriferids of China: Palaeont. Sinica, ser. B., v. 11, no. 1, 133 p.

Churkin, Michael, Jr., and Brabb, E. E., 1965, Ordovician, Silurian, and Devonian biostratigraphy of east-central Alaska: Am. Assoc. Petroleum Geologists Bull., v. 49, no. 2, p. 172-185.

Cooper, G. A., and Grant, R. E., 1966, Permian rock units in the Glass Mountains, west Texas: U.S. Geol. Survey Bull. 1244-E, p. E1-E9.

1969, New Permian brachiopods from west Texas: Smithsonian Contr. Paleobiology, no. 1, 20 p.

Dunbar, C. O., 1955, Permian brachiopod faunas of central east Greenland: Medd. om Grфnland, v. 110, no. 3, 169 p.

Dutro, J. T., Jr., 1961, Correlation of the Arctic Permian, in Geological Survey research 1961: U.S. Geol. Survey Prof. Paper 424-C, p. C225-C228.

Frebold, Hans, 1937, Das Festungsprofil auf Spitzbergen, [Part] 4-Die brachiopoden- und Lamellibranchiatenfauna und die Stratigraphie des Oberkarbons und Unterperms: Skr. Svalbard Ishavet 69, $94 \mathrm{p}$.

1950, Stratigraphie und Brachiopodenfauna des marinen Jungpaleozoikums von Holms und Andrups Land (Nordostgrönland): Medd. om Grфnland, v. 126, no. 3, 97. $p$.

Gobbett, D. J., 1963, Carboniferous and Permian brachiopods of Svalbard: Norsk Polarinst. Skr. 127, 201 p.

Grant, R. E., 1968, Structural adaptation in two Permian brachiopod genera, Salt Range, West Pakistan: Jour. Paleontology, v. 42 , no. 1, p. 1-32.

Häntzschel, Walter, 1962, Trace fossils and problematica, in Moore, R. C., ed., Treatise on invertebrate paleontol-
ogy-Part W, Miscellanea: New York and Lawrence, Kans., Geol. Soc. America and Kansas Univ. Press, p. W177-W245.

Harker, Peter, and Thorsteinsson, Raymond, 1960, Permian rocks and faunas of Grinnell Peninsula, Arctic Archipelago: Canada Geol. Survey Mem. 309, 89 p.

Keyserling, A. F., 1846, Wissenschaftliche Beobachtungen auf einer Reise in das Petschora-Land, in Jahre, 1843: St. Petersburg, Geognostiche Beobachtungen, p. 149-406.

Laudon, L. R., Hartwig, A. E., Morgridge, D. L., and Omernik, J. B., 1966, Middle and Late Paleozoic stratigraphy, Alaska-Yukon border area between Yukon and Porcupine Rivers: Am. Assoc. Petroleum Geologists Bull., v. 59, no. 9 , p. 1868-1889.

Likharev, B. K., and Einor, O. L., 1939, Materiali k poznaniyo Verkhnepaleosolskikh faun Novoi Zemli Brachiopoda, Paleontologiya Sovietskoi Arktiki, no. 4: Arkticheskogo Nauchno-Issled. Inst. Trudy, v. 127, 245 p.

Logan, A., 1966, The Upper Paleozoic productoid brachiopod Horridonia timanica (Stuckenberg) and its close relatives: Leeds Geol. Assoc. Trans., v. 7, pt. 4, p. 193-210.

Mertie, J. B., 1930, Geology of the Eagle-Circle district, Alaska: U.S. Geol. Survey Bull. 816, 168 p.

1933, The Tatonduk-Nation district, Alaska: U.S. Geol. Survey Bull. 836-E, p. 347-443.

1937, The Yukon-Tanana region, Alaska: U.S. Geol. Survey Bull. 872, 276 p.

Moore, R. C., ed., 1965, Treatise on invertebrate paleontology-Part H, Brachiopoda: New York and Lawrence, Kans., Geol. Soc. America and Kansas Univ. Press, 927 p.

Muir-Wood, H. M., 1962, On the morphology and classification of the brachiopod suborder Chonetoidea: British Mus. (Nat. Hist.) Mon., 132 p.

Nassichuk, W. W., Furnish, W. M., and Glenister, B. F., 1965, The Permian ammonoids of Arctic Canada: Canada Geol. Survey Bull. 131, 56 p.

Nelson, S. J., 1961a, Permo-Carboniferous of the northern Yukon Territory: Alberta Soc. Petroleum Geologists Jour., v. 9, p. 1-9.

1961b, Mississippian faunas of western Canada: Geol. Assoc. Canada Spec. Paper 2, 39 p.

1962a, Permo-Carboniferous tabulate corals from western Canada: Jour. Paleontology, v. 36, no. 5, p. 953-964. 1962b, Horridonid brachiopods as horizon indicators, Permo-Pennsylvanian of the Yukon Territory: Alberta Soc. Petroleum Geologists Jour., v. 10, no. 4, p. 192-197. Nelson, S. J., and Johnson, C. E., 1968, Permo-Pennsylvanian brachythyrid and horridonid brachiopods from the Yukon Territory, Canada: Jour. Paleontology, v. 42, no. 3, p. 715-746.

Pavlova, Y. Y., 1965, Reviziya roda Neophricodothyris (otryad Spiriferida): Paleont. Zhur., no. 2, p. 133-137 (translation in Internat. Geology Rev., 1966, v. 8, no. 1, p. 84-88).

Permian Subcommittee of National Research Council's Committee on Stratigraphy, Dunbar, C. O., chm., 1960, Correlation of the Permian formations of North America: Geol. Soc. America Bull., v. 71, no. 12, pt. 1, p. 1763-1805.

Ross, C. A., 1967, Late Paleozoic Fusulinacea from northern Yukon Territory: Jour. Paleontology, v. 41, no. 3, p. 709-725.

Scott, R. A., and Doher, L. I., 1967, Palynological evidence for Devonian age of the Nation River Formation, east-central 
Alaska, in Geological Survey research 1967: U.S. Geol. Survey Prof. Paper 575-B, p. B45-B49.

Skinner, J. W., and Wilde, G. L., 1966, Permian fusulinids from Pacific northwest and Alaska: Kansas Univ. Paleont. Contr., Paper 4, 64 p.

Spurr, J. E., 1898, Geology of the Yukon gold district: U.S. Geol. Survey 18th Ann. Rept., pt. III, p. 87-392.

Stepanov, D. L., 1937, Permskie brakhiopodi Spitsbergena: Arkticheskogo Nauchno-Issled. Inst. Trudy, v. 76, p. 105192.

Toula, F., 1875, Permo-Carbon-Fossilien von der Westkuste von Spitzbergen: Neues Jahrb. Mineralogie, Geologie u. Paleontologie, p. 225-264.

Tschernyschev, T., 1902, Verkhnekamennougolniya brakhiopodi Urala i Timana [Die obercarbonischen Brachiopoden des Ural und des Timan]: Geol. Komiteta Trudy (Mém. Comité Géol.), v. 16, no. 2, p. 1-432 (Russian); p. 433749 (German).
Tschernyschev, T., and Stepanov, P., 1916, Oberkarbonfauna von König Oscars und Heibergs Land, in Norwegian Arctic Exped. in "Fram," 2d, Rept. 34: Vidensk.-Selsk. Kristiania, $67 \mathrm{p}$.

Ustritskii, B. I., and Chernyak, G. E., 1963, Biostratigraphiya i brakhiopodi Verkhnego Paleozoya Taymira: NauchnoIssled. Inst. Geologii Arktiki Trudy, v. 134, 139 p.

Waterhouse, J. B., 1968, New species of Megousia MuirWood and Cooper and allied new genus from the Permian of Australia and North America: Jour. Paleontology, v. 43 , no. 5, p. 1171-1185.

Whitfield, R. P., 1908, Notes and observations on Carboniferous fossils and semifossil shells brought home by members of the Perry Expedition: Am. Mus. Nat. History Bull., v. 24, no. 2, p. 51-58.

Wiman, C., 1914, U̇ber die Karbonbrachiopoden Spitzbergens und Beeren Eilands: Nova Acta Regiae Societatis Scientiarum Upsaliensis, 4th ser., v. 3, no. 8, 91 p. 



\section{INDEX}

[Italic page numbers indicate both major references and descriptions]

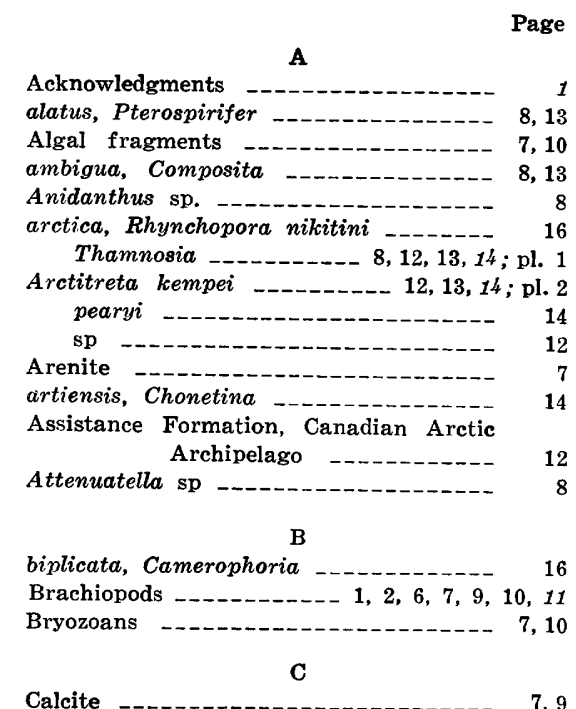

Calico Bluff Formation 9

Calliprotonia sp _... 8, 13

Camerophoria biplicata spitzbergiana _... 16

Cancrinella _..._... 14

tenuissima

sp _...

Chert _..... 2, 7, 10, 11

Chert-pebble conglomerate

Chonetina _.....- 14

artiensis _.......... 14

superba

sp _-

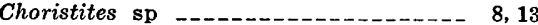

Cleiothyridina sp _._._._._. $8,12,13$

Composita ambigua _._._-_._- 8, 13

Corals _...... 2, 7, 10

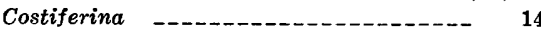

indica -

Craspedalosia sp _..._. 8, 13

Crurithyris sp _._._.

Cyclolobus

D

Derbyia grandis -_- 12 sp _. Dielasma timanicum _...... 8,13 dorotheevi, Linoproductus _._._-_._ 8,15 draschei, Spirifer _..._... 17 Spiriferella _..._-_ 8, 12, 13, 17; pl. 2 duplex, Yakovlevia _..... 16

Faulting

F

Foldvik Creek Formation

east Greenland _.......- 13

Foraminifers freboldi, Lingula _..._........ 8, 13

G

Glauconite

$7,9,10,11$

Glenn Shale _._...... 11

grandis, Derbyia _._. 12 granulifera, Horridonia granuliferus, Productus horridus _...- 15 greenlandica, Martinia _._._._. 8, 17 Yakovlevia _._._-_._._._. 12, 16 Grumantia

kempei

\section{Page granulifera - timanica sp _-_. 8,12 horridus granuliferus, Productus _... 15 Hustedia sp _._._._._. 8, 13 Hystrichosphaerids \\ I \\ impressa, Yakovlevia} indica, Costifera _._. Introduction irginae, Waagenoconcha _- 8, 12, 13, 16; pl. 1 irginaeformis, Waagenoconcha $-8,14,16 ;$ pl. 2

\section{$\mathrm{K}$}

keilhavi, Spiriferella 8,12 kempei, Arctitreta _._._._. 12, 13, 14; pl. 2 Grumantia Streptorhynchus kochi, Rhynchopora _-_._-_ 12, 13, 16; pl. 1 Stenoscisma Kochiproductus sp Krotovia sp _..... 8, 12, 13 kutorgae, Septacamera _._._ 8, 13, 16 ; pl. 2 Kuvelousia sphiva _..._........ 8, 13, 15; pl. 2 weyprechti L

Leonard Series, Southwestern United States

Licharewia sp _Lingula freboldi sp _........ 8 Linoproductus _._. dorotheevi 8,15 schrencki _.......... $8,13,15 ;$ pl. 1 sp _._. Liosotella proboscides pseudohorrida _...__- $8,12,13,15 ;$ pl. 1 sp _-_-_.....-.-. 8 Lissochonetes spitzbergiana _- 12, 13, 14 ; pl. 2 sp. _..._. Locality descriptions M

nammata, Muirwoodia Yakovlevia mammatus, Productus Martinia greenlandica _._________- 8, 17 sp. A _. sp Megousia sp $\ldots \ldots$ Mertie, J. B., quoted Muirwoodia _... 16 mammata _._. 16

$\mathrm{N}$

Nation, Alaska _._.

Nation River _................ 1, 2, 7, 11 Nation River Formation Neochonetes _-_. 14 sp _............. 8, 12, 13 Neophricadothyris _._. 17 Neospirifer _...- 17 striatoparadoxus _....._. $8,13,1 \pi ; \mathrm{pl} .2$ sp _._._._. 8,12 nikitini arctica, Rhynchopora nodosa, Permophricodothyris _- $8,13,17$, pl. 1 Squamularia o

Page

Odontospirifer $\mathrm{sp}$ Ogilvie Mountains, Yukon Territory, Canada _... 2, 12 Orbiculoidea sp

\section{$\mathbf{P}$}

Paleosol

payeri, Waagenoconcha pearyi, Arctitreta ...--_-_-_-_ 14 Pelmatozoans _- 7,10 Permophricodothyris _..._-_._-_._ 17 nodosa _._._._. $8,13,17 ;$ pl. 1 sp _-_. Phricodothyris -

Plant fragments _._. 6.9 Pojeta, John, Jr., written

communication _-._-_.. 7

Pollen
Previous work on Tahkandit Limestone

proboscides, Liosotella _-_-_-_-_ 12

Productus - 14 horridus granuliferus mammatus _._._._._._. 16 pseudohorridus _-_-_-_-__-__- 15

Psilocamara sp --_---_--_- 8 pseudohorrida, Liosotella $--8,12,13,15 ;$ pl. 1 pseudohorridus, Productus _._._._... 15 Pterospirifer alatus _-_-_ 8,13 sp --Pulchratia sp

Quartz Q 7,10 $\mathbf{R}$

Rhipidomella sp _-_Rhynchopora -....- 16 kochi -._-_-_._-_- 12, 13, 16; pl. 1 nikitini arctica sp _..._. 8, 12

Road Canyon Formation, Tex _.... 11 $\mathbf{S}$

saranae, Spiriferella _______ 8, 13, 17; pl. 1 schrencki, Linoproductus _-.- 8, 13, 15; pl. 1 Schuchertella sp _-__-__. 8

Scott, Richard A., written

Septacamera kutorgae

Siltstone -._...-. 2

Slough section of Tahkandit Limestone - 10

Slump structures _._._._._._._. 9, 11 sphiva, Kuvelousia _..._..- 8, 13, 15; pl. 2 Spirifer _. draschei

Spiriferella _draschei keilhavi _._._._. 8, 12 caranae _-_-_-_-_-_- 8, 13, 17; pl. 1 sp _... 8,12

Spirophyton sp -..- 9 spitzbergiana, Camerophoria _...... 16 Lissochonetes _._._. 12, 13, 14; pl. 2 Stenoscisma _.._____ 8, 13, 16; pl. 2 Spores _Spurr, J. G., quoted Squamularia nodosa _..-_-_._._. 17

Stenoscisma _._._. kochi spitzbergiana

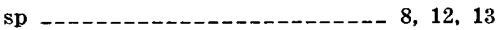




\section{PLATE 1}

[See p. 18-21 for locality descriptions]

Figures 1-5, 18-20. Liosotella pseudohorrida (Wiman).

1-4. Silicified ventral valve. Ventral, posterior, side, and interior views, $\times 1$, USGS loc. 23052-PC, sandstone unit, 60 feet above base.

5. Dorsal valve interior, calcareous, $\times 1$, USGS loc. $21751-P C$, at top of limestone unit.

18-20. Calcareous shell, partially exfoliated, posterior, ventral, and side views, $\times 1$, USGS loc. 23055-PC, at base of limestone unit.

6-8. Permophricodothyris cf. P. nodosa (Chao).

Nearly complete shell, partially silicified, $\times 1$, USGS loc. 23051-PC, sandstone unit, 53 feet above base.

9-12, 33-36. Yakovlevia mammata (Keyserling).

9-12. Silicified shell. Dorsal, ventral, anterior (showing spine bases), and side views, $\times 1$, USGS loc. 23051-PC, sandstone unit, 53 feet above base.

33-36. Sicilified shell. Ventral, dorsal, anterior, and side views, $\times 1$ (hinge ends showing spine bases), USGS loc. 23051-PC, sandstone unit, 53 feet above base.

13-17. Spiriferella cf. S. saranae (Verneuil).

Juvenile shell. Dorsal, ventral, posterior, side, and anterior views, $\times 1$, USGS loc. 23051-PC, sandstone unit, 53 feet above base.

21. Kuvelousia cf. K. weyprechti (Toula).

Ventral valve, ventral view, $\times 1$, USGS loc. 22331-PC, Tahkandit Limestone.

22-26. Rhynchopora kochi Dunbar.

Complete shell. Dorsal view, $\times 2$ and $\times 1$, side, anterior, and ventral views, $\times 1$, USGS loc. 22332-PC, Tahkandit Limestone.

27-30. Martinia sp. undet.

Silicified ventral valve. Interior views, $\times 1$ and $\times 2$, side and ventral view, $\times 1$, USGS loc. 23050-PC, sandstone unit, 49 feet above base.

31, 32. Cancrinella sp. undet.

Two calcareous shells, ventral views, $\times 1$, USGS loc. 23053-PC, sandstone unit, 66 feet above base.

37. Chonetina? cf. C. superba Gobbett.

Large ventral valve having spines. Ventral view, $\times 1$, USGS loc. 23085-PC, lower part of limestone unit.

38, 39, 45. Thamnosia cf. T. arctica (Whitfield).

38, 39. Broken silicified shell. Side and ventral views, $\times 1$, USGS loc. 23049-PC, sandstone unit, 47 feet above base.

45. Smaller shell. Dorsal view, $\times 1$, USGS loc. 23050-PC, sandstone unit, 49 feet above base.

40,41. Linoproductus cf. L. schrencki (Stuckenberg).

Medium-size ventral valve. Side and ventral views, $\times 1$, USGS loc. 23054-PC, top of sandstone unit.

42-44. Waagenoconcha cf. W. irginae (Stuckenberg).

Partially exfoliated shell. Dorsal, ventral, and side views, $\times 1$, USGS loc. 21743-PC, Tahkandit Limestone.

46, 47. Horridonia granulifera (Toula).

46. Calcareous ventral valve, partially exfoliated, ventral view, $\times 1$, USGS loc. 23055-PC, limestone unit.

47. Calcareous ventral valve, slightly exfoliated, oblique view, $\times 1$, USGS loc. 23055-PC, base of limestone unit. 


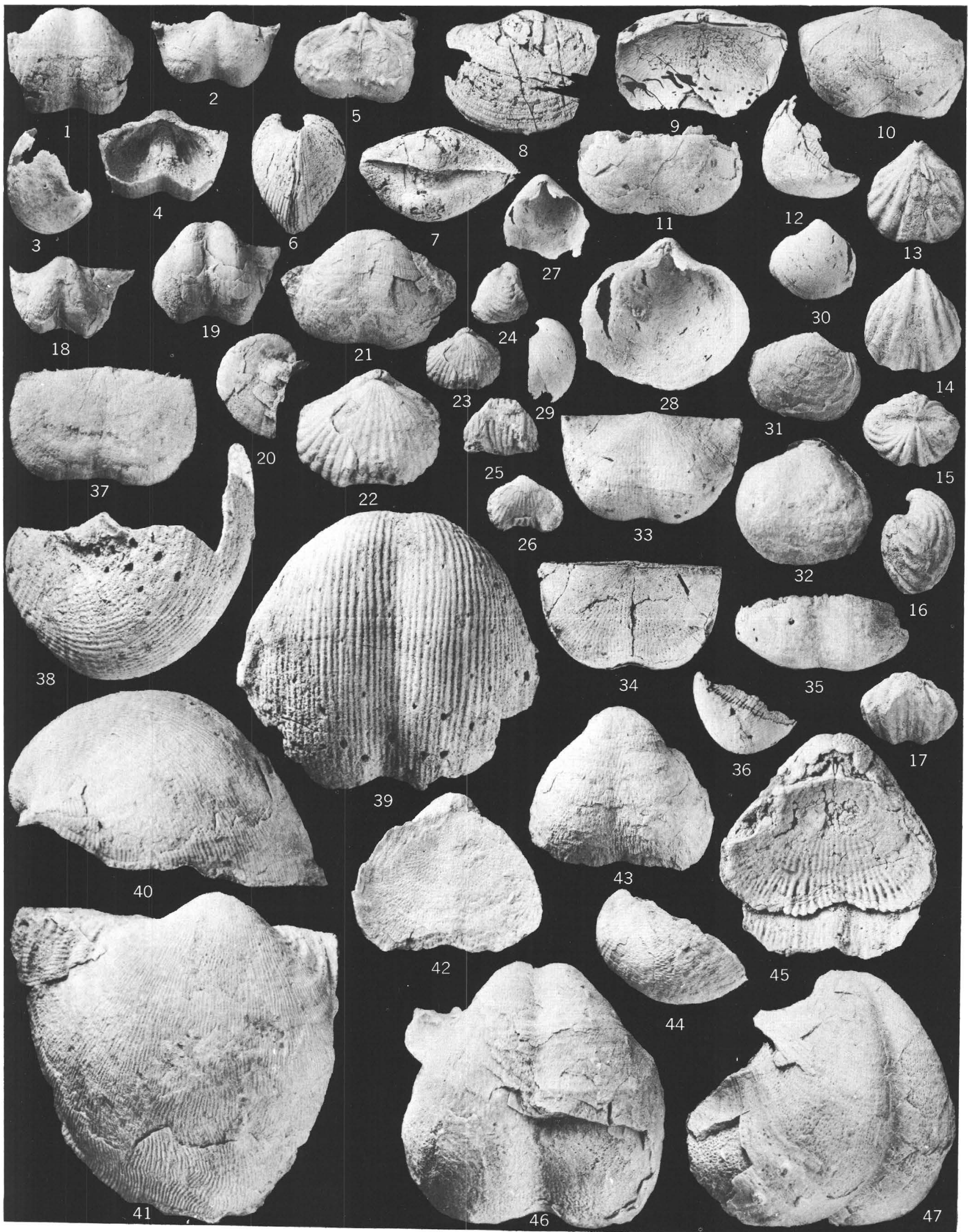

FOSSILS FROM THE TAHKANDIT LIMESTONE 


\section{PLATE 2}

[See p. 18-21 for locality descriptions]

Figures 1-4, 11. Kuvelousia sphiva Waterhouse.

1. Shell having part of right ear. Dorsal view, $\times 1$, USGS loc. 23062-PC, limestone unit, 15 feet below top.

2-4. Partially exfoliated shell. Ventral, posterior, and side views, $\times 1$, USGS loc. 23062-PC, limestone unit, 15 feet below top.

11. Dorsal valve. Interior oblique view, $\times 1$, showing part of ear and thickness of valve at anterior, USGS loc. 21788-PC, limestone unit, about 15 feet below top.

5-10. Megousia sp. undet.

5. Slightly exfoliated ventral valve. Ventral view, $\times 1$, USGS loc. 21794-PC, limestone unit, about 35 feet above base.

6, 7. Somewhat wider ventral valve. Posteroventral and oblique views, $\times 1$, USGS loc. 21794-PC, limestone unit, about 35 feet above base.

8. Dorsal valve. Interior view, $\times 1$, USGS loc. 21794-PC, limestone unit, about 35 feet above base.

9. Dorsal valve. Interior view, $\times 2$, showing anterior rim, cardinal process, and median septum, USGS loc. 21794-PC, limestone unit, about 35 feet above base.

10. Dorsal valve. Interior view, $\times 2$, showing anterior rim and much of right ear, USGS loc. 21794-PC, about 35 feet above base.

12-14. Neospirifer cf. N. striatoparadoxus (Toula).

Shell almost completely exfoliated. Dorsal, anterior, and side views, $\times 1$, USGS loc. 23062-PC, limestone unit, 13-15 feet below top.

15-17. Lissochonetes cf. L. spitzbergiana (Toula).

Small complete shell. Dorsal view, $\times 2$, ventral views, $\times 1$ and $\times 2$, USGS loc. 23083-PC, lower part of limestone unit.

18, 19. Cancrinella sp. undet.

Almost entirely exfoliated ventral valve. Side and ventral views, $\times 1$, USGS loc. 21794-PC, limestone unit, about 35 feet above base.

20. Septacamera cf. S. kutorgae (Tschernyschev).

Fragment of dorsal valve. Side view, $\times 1$, USGS loc. 21760-PC, limestone unit, 23 feet above base.

21,22, 25. Arctitreta cf. A. kempei (Andersson).

21,22. Silicified juvenile ventral valve. Exterior view, $\times 1$, interior view, $\times 2$, USGS loc. $23083-$ $\mathrm{PC}$, lower part of limestone unit.

25. Large calcareous ventral valve having attached ventral valve of Kuvelousia sphiva, $\times 1$, USGS loc. 23062-PC, limestone unit, 13-15 feet below top.

23,24. Waagenoconcha ef. W. irginaeformis (Stepanov).

23. Flat calcareous ventral valve, $\times 1$, USGS loc. 23061-PC, limestone unit, 150 feet below top.

24. Natural impression of dorsal exterior, $\times 1$, USGS loc. 23061-PC, limestone unit, 150 feet below top.

26-28, 34, 35. Spiriferella draschei (Toula).

26, 28. Large calcareous shell. Dorsal and anterior views, $\times 1$, USGS loc. 23083-PC, lower part of limestone unit.

27. Large calcareous shell. Side view, $\times 1$, USGS loc. 23083-PC, lower part of limestone unit.

34. Silicified ventral valve. Posterior view, $\times 1$, USGS loc. 21748-PC, limestone unit.

35. Silicified ventral valve. Ventral view, $\times 1$, USGS loc. $21748-P C$, limestone unit, 240 feet below top.

29-33. Stenoscisma spitzbergiana (Stepanov).

Steinkern having shell mostly exfoliated. Dorsal, posterior, ventral, anterior, and side views, $\times 1$, USGS loc. 23048-PC, sandstone unit, 45 feet above base. 


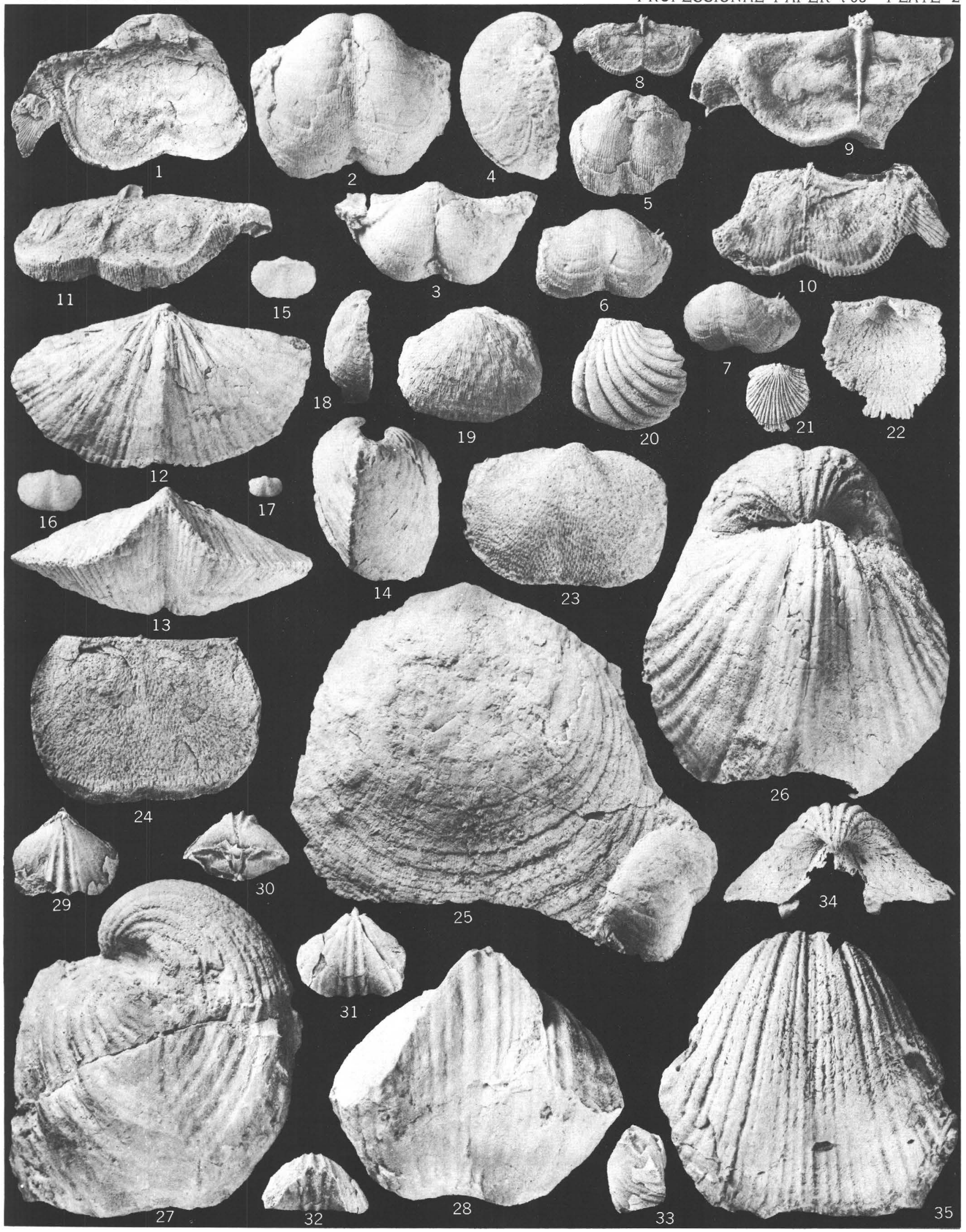

FOSSILS FROM THE TAHKANDIT LIMESTONE 
